\title{
Modeling the role of reservoirs versus floodplains on large-scale river hydrodynamics
}

\author{
Ayan Fleischmann ${ }^{1}$ (D) Walter Collischonn ${ }^{1} \cdot$ Rodrigo Paiva $^{1} \cdot$ Carlos Eduardo Tucci $^{1}$
}

Received: 28 December 2018 / Accepted: 18 September 2019 / Published online: 24 September 2019

(c) Springer Nature B.V. 2019

\begin{abstract}
Large-scale hydrologic-hydrodynamic models are powerful tools for integrated water resources evaluation at the basin scale, especially in the context of flood hazard assessment. However, recent model developments have paid little attention to simulate reservoirs' hydrodynamics within river networks. This study presents an adaptation of the MGB model to simulate reservoirs as an internal boundary condition, enabling the explicit simulation of hydrodynamic processes along reservoirs and their interaction with upstream and downstream floodplains in large basins. A case study is carried out in the Itajaí-Açu River Basin in Brazil, which has periodic flood-related disasters and three flood control dams. The model was calibrated for the 1950-2016 period forced with daily observed precipitation. The adjustment was satisfactory, with Nash-Sutcliffe metrics between 0.54 and 0.84 for the 11 gauges analyzed and with flood frequency curves also well represented. Simulation scenarios with and without floodplains and reservoirs were performed to evaluate the relative role of these factors on flood control basin-wide through evaluation of simulated discharges, water levels and flood extent. Itajaí do Oeste tributary and Itajaí-Açu mainstem present major floodplain attenuation, while in Itajaí do Sul and Itajaí do Norte tributaries the main flood control occurs due to reservoir attenuation. Downstream from the dams, results indicated that the reservoirs reach their maximum discharge reduction capacity for 5- to 10-year floods, decreasing it for larger floods. The developed model may be very useful for operational uses as flood forecasting and coordinated reservoir operation studies, as well as to enhance the comprehension of flood dynamics at basin scale.
\end{abstract}

Keywords Reservoirs · Flood control · Floodplains · Hydrodynamic modeling · Itajaí-Açu River Basin

Ayan Fleischmann

ayan.fleischmann@gmail.com

Walter Collischonn

collischonn@iph.ufrgs.br

Rodrigo Paiva

rodrigocdpaiva@gmail.com

Carlos Eduardo Tucci

carlos.tucci@rhama.com.br

1 Instituto de Pesquisas Hidráulicas, Universidade Federal do Rio Grande do Sul, Av. Bento Gonçalves, 9500, Porto Alegre, RS 91501-790, Brazil 


\section{Introduction}

Floods are among the most relevant disasters worldwide (EM-DAT 2012). Increasing interaction and exposure between human systems and river floodplains, as well as uncertainties in the context of a changing climate (Di Baldassarre et al. 2013, 2018; Hirabayashi et al. 2013; Blöschl et al. 2015; Winsemius et al. 2016), highlight the importance of improving our capability to evaluate flood control measures and understand the associated changes on variables as water level, discharge, floodplain storage and water velocity. Large-scale hydrologic models are powerful tools for flood-related studies such as prediction of future flood risk under climate change (Hirabayashi et al. 2013; Winsemius et al. 2016; Ribeiro Neto et al. 2016), flood hazard mapping (Pappenberger et al. 2012) and flood forecasting (Alfieri et al. 2013; Paiva et al. 2013; Fan et al. 2016; Siqueira et al. 2016a; Casagrande et al. 2017). Recent years have seen a major development of coupling strategies between hydrologic and 1D and 2D hydrodynamic models (Biancamaria et al. 2009; Yamazaki et al. 2011; Neal et al. 2012; Paiva et al. 2013; Schumann et al. 2013; Seibert et al. 2014; Hoch et al. 2017a; Pontes et al. 2017; Fleischmann et al. 2018), which relevance was generally justified by a misrepresentation of flood dynamics in simpler models (e.g., flood peak attenuation due to floodplains, flood wave diffusion). Many efforts have led to the creation of computationally efficient $2 \mathrm{D}$ or quasi-2D hydraulic approaches aiming at further improving the representation of flood variables (e.g., velocity, water depth) (Bates and De Roo 2000; Bates et al. 2010; Paz et al. 2011; Neal et al. 2012), although 1D hydrodynamic models such as HEC-RAS (USACE 2010) are still highly used in both academic and operational studies and have been proven satisfactory for many applications (Horritt and Bates 2002).

Although these large-scale hydrologic-hydrodynamic models have been successfully applied in different basins worldwide, few attempts have been made to simulate and predict the effect of multiple reservoirs on flood control. A typical hydrologic-hydrodynamic approach for operational uses involves forcing a 1D or 2D hydrodynamic model (e.g., HEC-RAS model) with simulated dam-regulated discharges from a hydrologic model that considers a reservoir unit in its propagation (e.g., HEC-HMS model) (Gül et al. 2010; Yazdi and Salehi Neyshabouri 2012; Seibert et al. 2014; Falter et al. 2016; Tanaka et al. 2017; Yoshimoto and Amarnath 2018). The adopted domain for the hydrodynamic model in these studies usually involves only major floodplain areas in downstream regions.

For large scales (i.e., from dozens to millions of $\mathrm{km}^{2}$ ), it is generally difficult to implement detailed hydraulic models as HEC-RAS for the whole basin domain, which typically require surveyed channel cross sections and user intensive data preparation. Some models have been recently developed to fulfill this gap, such as the subgrid LISFLOOD-FP (Neal et al. 2012), CaMa-Flood (Yamazaki et al. 2013), MGB (Pontes et al. 2017) and HyMAP (Getirana et al. 2017), using the computationally efficient inertial routing method proposed by Bates et al. (2010) and simplified river cross sections. At regional to continental and global scales, recent developments of global hydrologic models have also pointed to the necessity of simulating reservoirs and simplified operation rules in hydrologic models (Hanasaki et al. 2006; Döll et al. 2009; Yoon and Beighley 2015; Zhou et al. 2016; Zajac et al. 2017; Shin et al. 2019). A pioneer study was carried out by Mateo et al. (2014), who forced the CaMa-Flood global hydrodynamic routing model with the H08 global hydrologic model with a reservoir propagation routine to evaluate the effects of two major reservoirs on the Chao-Phraya basin 2011 flood event. Recently, Pokhrel et al. (2018) coupled the HiGW-MAT hydrologic model to CaMa-Flood in the Mekong River Basin to assess 
reservoir impacts on the flood pulse dynamics. Moreover, Shin et al. (2019) presented a first continental-scale hydrodynamic model capable of simulating the dynamics of reservoirs and applied the developed LEAF-Hydro-Flood-Dam model to the CONUS domain.

Instead of forcing a large- to regional-scale hydrodynamic model with outputs from a hydrologic one, there is now an interesting opportunity for fully coupling hydrologic and hydrodynamic processes within one only model structure (Hoch et al. 2017b; Fleischmann et al. 2018). Reservoirs could then be dynamically represented within the simulated drainage network as internal boundary conditions, moving away from lumped, level-pool routing methods (Fread 1992), and representing hydrodynamic processes along the reservoir tributaries (e.g., backwater effects and flood wave diffusion) (Shin et al. 2019). It could also dynamically consider the fraction of reservoir area that is flooded, the remaining fraction subjected to open soil/vegetation hydrologic processes and interactions between floodplains and adjacent soils.

Explicitly simulating reservoirs and floodplains hydrodynamics at the whole basin scale within large-scale models may improve integrated water resources assessment. For example, while the role of reservoirs and floodplains in attenuating floods at the basin scale is generally understood (Yamazaki et al. 2011; Paiva et al. 2013; Zhou et al. 2016), the comprehension of the relative importance of each one could be improved with such integrated basin models. This is very relevant in basins with multiple reservoirs and with floodplains presented both upstream and downstream from dams. In this context, the present study aims to develop and present the application of a coupled large-scale hydrologic-hydrodynamic model with multiple reservoirs for flood control and to evaluate the relative roles of reservoir and floodplains in controlling flooding. The MGB model (Collischonn et al. 2007; Pontes et al. 2017) is adapted for reservoir simulation and is applied to the Itajaí-Açu River Basin in Brazil. The basin is selected due to its long history of flood-related damages across the basin and the existence of dams with flood control only purpose. The model development for this basin may also provide a very useful tool for basin-scale operational uses.

\section{Study area: the Itajaí-Açu River Basin}

The Itajaí-Açu River Basin is a $15,000 \mathrm{~km}^{2}$ watershed located in Southern Brazil in the Santa Catarina State, with a Köppen Cfa temperate climate and an original rainforest cover. Around 1.5 million people live in the basin. Agriculture occurs along the fertile floodplains of the valleys of the Itajaí-Açu river and its tributaries, while most economically important cities are also located along the floodable areas, including Rio do Sul, Blumenau, Brusque and Itajaí. The Itajaí-Açu River is formed by three main tributaries, Itajaí do Sul (southern tributary), Itajaí do Oeste (western tributary) and Itajaí do Norte (northern tributary) rivers (Fig. 1a). After the confluence between Itajaí do Sul and Itajaí do Oeste rivers, the main channel is called Itajaí-Açu River.

Figure 1b, c presents the basin topography based on the DEM used in this study and the basin HAND (height above nearest drainage; Rennó et al. 2008) contour map, respectively (see Sect. 3.3 for more details). The DEM shows the large floodplains occurring even in upstream headwater catchments at $\sim 500 \mathrm{~m}$ elevation, while low HAND values highlight the floodplains existing in the Itajaí do Oeste River and along the Itajaí-Açu mainstem, especially in its most downstream reaches. 


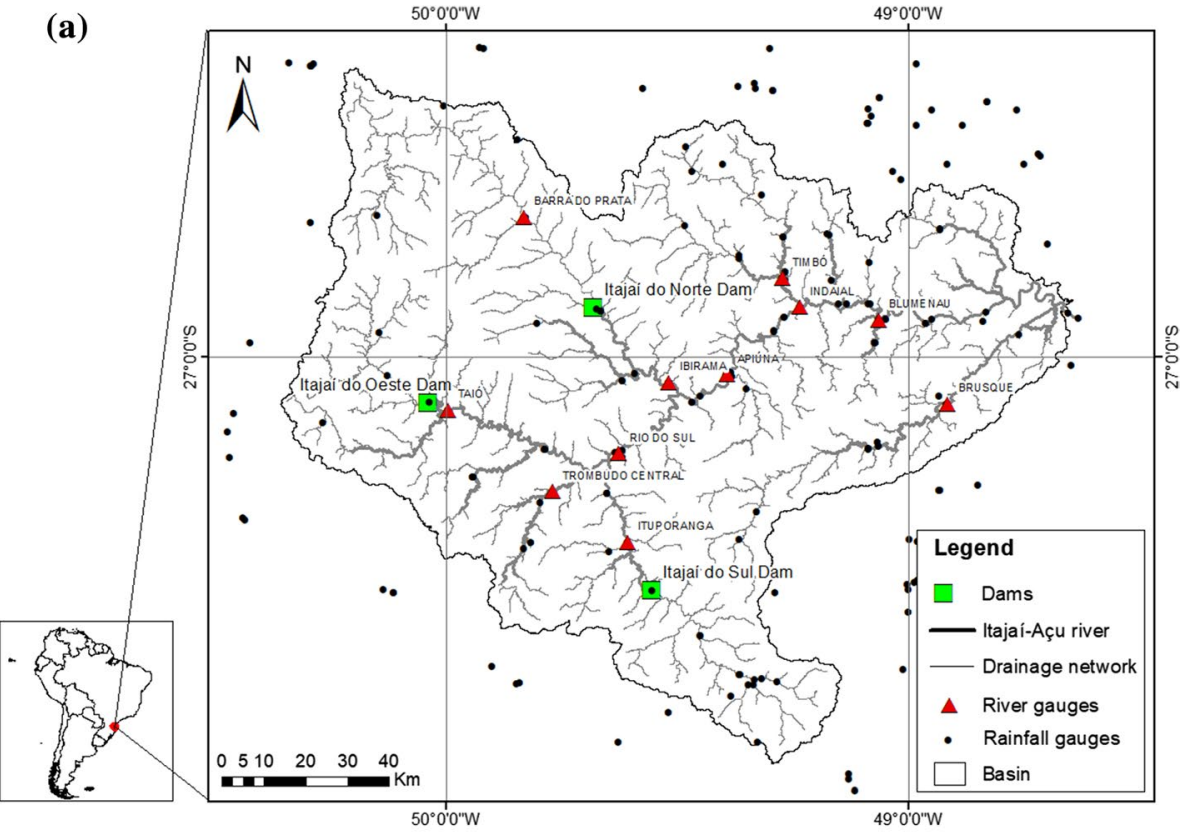

(b)

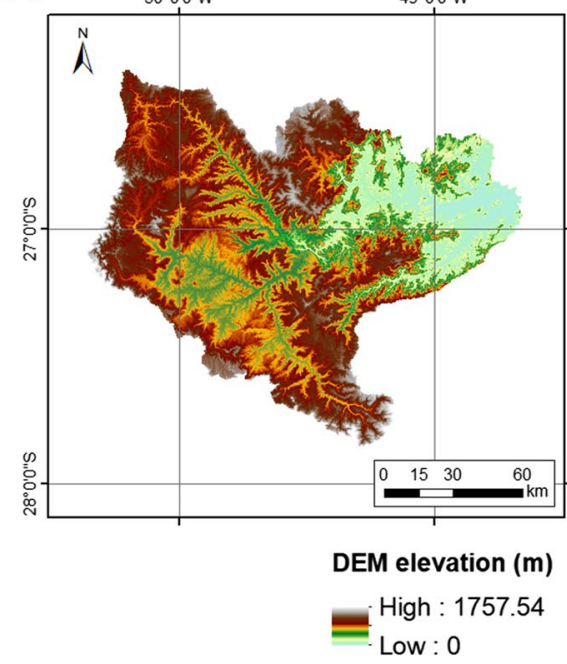

(c)

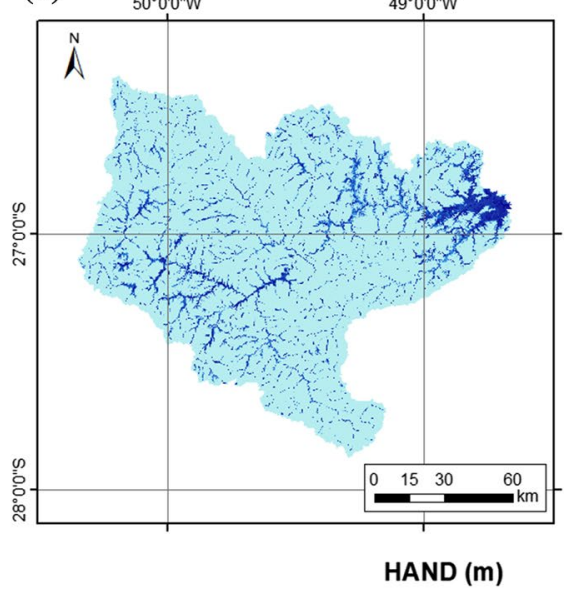

HAND (m)

Fig. 1 a The Itajaí-Açu River Basin, its main tributaries, cities, flood control dams, and precipitation and discharge gauges used for model calibration; b digital elevation model; c HAND contour map for the ItajaíAçu River Basin showing flood-prone areas

Since the earlier European settlements across the Itajaí valley in the XIX century, major floods have periodically been recorded, affecting thousands of people and leaving high economic losses (Frank 2003). The 1983 flood, one of the largest events in the observed data, led to estimated U\$ 1.1 billion damage across the basin (Frank 2003). Furthermore, three out of the ten Brazilian cities with highest number of displaced people due to disasters 
are estimated to be located in the basin, including Blumenau, which according to Igarapé (2018) had the highest figure in the country with around 140,000 displaced people in the 2000-2017 period due to flood-related disasters. Floods can occur in any period of the year (e.g., the 1983 large flood occurred in July while the 2011 one was in September) due the non-seasonality of the precipitation regime in the basin. Average annual rainfall is $1600 \mathrm{~mm}$.

In the basin, there are three large reservoirs built for the only purpose of flood control (Pinheiro and Frank 2003), which represent some of the few cases of dams designed only for flood control in Brazil. Each reservoir is located in one of the main Itajaí-Açu tributaries, Itajaí do Oeste (drainage area $\left.855 \mathrm{~km}^{2}\right)$, Itajaí do Sul $\left(1171 \mathrm{~km}^{2}\right.$ ) and Itajaí do Norte $\left(2336 \mathrm{~km}^{2}\right)$ dams, which were built in 1973, 1975 and 1993, respectively. All of them have gated outlet works and a free spillway. While the former two dams are currently operated during floods, the Itajaí do Norte one is usually not operated due to sociopolitical issues between the reservoir operator (i.e., Santa Catarina State) and the local indigenous community.

In recent years, several large floods have again affected the basin (e.g., the 2011 flood), which pushed new plans to improve flood control capabilities across the basin (JICA 2011), including projects for building new flood control dams, levees and floodways (diversion canals). In 2015, the spillway crests of Itajaí do Oeste and Itajaí do Sul dams were increased, and the Itajaí do Oeste dam crest was raised in order to increase the reservoir storage. Also, one new lateral tunnel was built in each dam to improve the reservoir emptying and its operation capacity during floods. Recent studies have also highlighted the relevance of improving flood risk management in the basin through flood forecasting (Casagrande et al. 2017) and flood hazard mapping (Nobre et al. 2016; Speckhann et al. 2018; Fleischmann et al. 2019).

\section{Methods}

\subsection{MGB model}

The MGB model (Collischonn et al. 2007; Pontes et al. 2017) is a semi-distributed rainfall-runoff model developed for simulation of large basins. In its most recent version, river maps are extracted from high-resolution DEMs using a vector-based approach and the basin is divided into unit-catchments, each one containing a single-river reach with associated floodplain and hydrologic vertical water and energy balance. Within each unit-catchment, hydrologic response units (HRUs) are defined based on soil type and land use, and for each one, the water and energy budget is computed through the soil-vegetation system. Evapotranspiration is computed using Penman-Monteith equation. Surface, subsurface and groundwater outflows from water balance are routed to the main river of the unit-catchment using linear reservoirs, while flow propagation through drainage networks is computed using either the Muskingum-Cunge method or 1D hydrodynamic equations (i.e., inertial method). Additionally, sub-basins are defined as macro-regions unifying many unitcatchments with the same model parameter values. For more details on the rainfall-runoff generation module, see Collischonn et al. (2007), Pontes et al. (2017) and Siqueira et al. (2018). The next sections present the model hydrodynamic propagation module together with the developed scheme for simulation of reservoirs, which is the focus of this study. 


\subsection{River hydrodynamic routing}

Pontes et al. (2017) presented the current MGB model version with 1D hydrodynamic propagation, using the inertial equations (i.e., Saint-Venant equations simplified by neglecting the convective acceleration term in momentum equation) explicit scheme proposed by Bates et al. (2010). Assuming a rectangular river cross section, discharge can be computed between two adjacent unit-catchments by numerical approximations as:

$$
Q_{\text {out }, i}^{t+\Delta t}=\left(\frac{\left(\left(Q_{i}^{t}\right)-g \cdot \text { Bflow }_{i} \cdot \Delta t \cdot\left(\text { hflow }_{i} \cdot \text { Sflow }_{i}\right)\right)}{\left(1+\frac{g \cdot \Delta t \cdot \text { hflow }_{i} \cdot\left(\left|Q_{i}^{t}\right|\right) \cdot n^{2}}{B \text { flow }_{i} \cdot\left(\text { hflow }_{i}\right)^{10 / 3}}\right)}\right)
$$

where $Q_{i}^{t+\Delta t}$ is the discharge at unit-catchment $i$ at time $t+\Delta t, n$ the Manning's coefficient, hflow $_{i}$ the flow depth between unit-catchments $i$ and $i+1$, Sflow $w_{i}$ the water level slope, $\Delta t$ the model time step, Bflow $w_{i}$ the flow width and $g$ the gravitational acceleration.

The continuity equation can be approximated for each unit-catchment river reach as:

$$
\frac{V_{i}^{t+\Delta t}-V_{i}^{t}}{\Delta t}=\sum Q_{\mathrm{in}, i}^{t+\Delta t}-Q_{\mathrm{out}, i}^{t+\Delta t}+Q_{\mathrm{local}}+P_{i}-E T_{i}
$$

where $V$ is the volume stored in unit-catchment $i, \sum Q_{i n, i}^{t+\Delta t}$ the sum of inflows from upstream unit-catchments, $Q_{\text {out }, i}^{t+\Delta t}$ the unit-catchment outflow, $Q_{\text {local }}$ the locally generated runoff, $P$ the precipitation over flooded areas (i.e., river reach surface area plus flooded floodplain or reservoir area) and ET the flooded area open water evaporation. Volume from the continuity equation is related to the unit-catchment water level through the level-area-volume relationship, which is derived for each unit-catchment with the IPH-HydroTools GIS toolkit (Siqueira et al. 2016b) using the height above nearest drainage (HAND) contour map method to derive flooded areas (Rennó et al. 2008). The Itajaí-Açu basin HAND map is presented in Fig. 1c. Below bankfull level, the unit-catchment flooded area is equal to the channel surface area. Bank elevation is derived from the average of DEM pixels above the unit-catchment river reach pixels, filtered with a linear regression (Siqueira et al. 2018). Model time step is computed with Courant-Friedrichs-Levy condition with an adjustment parameter $\propto$ (Bates et al. 2010).

In the model, a dynamic HRU (i.e., dynamic land cover) approach is adopted, whereby at each time step, for a given unit-catchment the local runoff is differed between hillslope generation and direct precipitation/evaporation on flooded areas according to the unitcatchment flooded area (i.e., channel surface water + floodplain flooded areas + reservoir lake area). Infiltration from floodplain into unsaturated soils is also possible (Fleischmann et al. 2018), but was not considered in this study.

\subsection{Reservoir routing}

Regarding reservoir simulation, Fread (1992) defines two main types: dynamic and lumped (level-pool) models. The latter computes a simple and lumped continuity equation for a given reservoir assuming a horizontal water level in the respective lake. The dynamic method, the one adopted in this study, considers a distributed modeling with Saint-Venant equations (full or simplified), with dams being represented as internal boundary conditions 
that can be, for example, a dam rating curve (e.g., breach, spillway, gate and dam crest flows). The level-pool method assumes a horizontal water surface and approaches the dynamic one if reservoir length is short, depth is large, inflow hydrograph volume is large and inflow hydrograph time of rise is long (Fread 1992).

To illustrate these differences, Fig. 2 shows the different processes represented in each simulation type. In hydrodynamic models with dynamic reservoir simulation (Fig. 2a), as done in this study, for a given reach one could analyze the synergic effects of backwater from a downstream reservoir (e.g., R1 in Fig. 2a), water releases from upstream reservoirs (e.g., R2 and R3 in Fig. 2a), dynamically varying land cover (i.e., a dynamic land cover fraction considering the proportion of a unit-catchment that is covered by water or not), floodplain attenuation, flood wave diffusion and distributed water inflows. When lumped routing models are performed, inflows are concentrated in the reservoir unit, and a proper

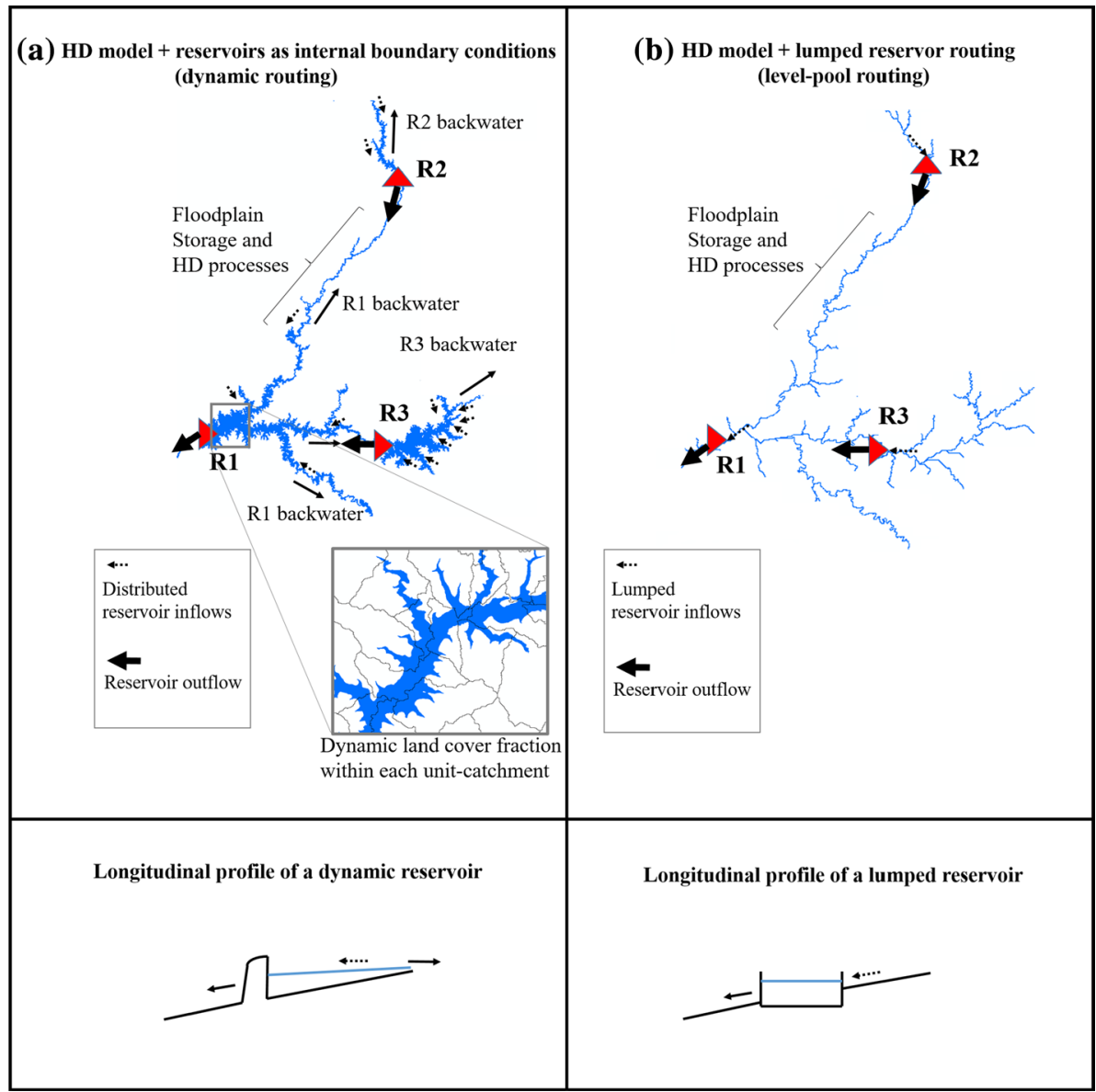

Fig. 2 Schematic representation of backwater effects, flood wave propagation, reservoir routing and dynamic land cover fraction within reservoir lakes' unit-catchments (gray polygons) in scenarios with a hydrodynamic (HD) model and reservoirs simulated as internal boundary conditions (BC), as implemented in this study, and b HD model and lumped (level-pool) reservoir routing. Hypothetical reservoirs R1, R2 and $\mathrm{R} 3$ are presented as an example 
accounting of hydrodynamic processes and energy interactions between lake and atmosphere (e.g., lake evaporation) is hampered (Fig. 2b).

In this study, a dynamic-based modeling framework is developed for the MGB model (i.e., Fig. 2a). Two main reservoir characteristics are considered: the reservoir storage (i.e., stage-area-volume relationship) and the hydraulic structures (i.e., equations that define the outflow at the dam location).

The variation of storage within the reservoir area is computed by the continuity equation (Eq. 2), considering the stage-volume relationship estimated from a DEM for each unitcatchment (i.e., the model discretization units). If the adopted DEM was created before the reservoir building, it will represent the reservoir bathymetry. However, if it does not correctly represent the bathymetry (for example if the DEM was obtained after the dam building, or if the DEM has large errors in comparison to a locally estimated bathymetry), the storage can be adjusted by replacing the respective unit-catchments' level-storage relationship by the correct one (i.e., distributing, for each water level, the reservoir storage across all unit-catchments). Alternatively, the DEM could be processed by introducing on it the reservoir bathymetry. In the Itajaí-Açu basin application, given the flood control only use of the basin dams (so that they are almost empty during non-flooding periods), the adopted DEM was directly used, since it represents the reservoirs' bathymetry.

The second characteristic that defines a reservoir within the MGB is its outflow equation (e.g., outlet works, spillway structures or a pre-defined operation rule for gates), considered as an internal boundary condition. It replaces the inertial momentum equation (Eq. 1) at the unit-catchment where the dam is located. For the three dams in the Itajaí-Açu basin, bottom outlet and spillway outflows are considered as the following rating curves:

$$
\begin{gathered}
Q_{\mathrm{ow}}=C_{\mathrm{ow}} A \sqrt{2 g\left(y-y_{\mathrm{ow}}\right)}, \\
Q_{\text {spill }}=C_{\text {spill }} L\left(y-y_{\text {spill }}\right)^{1.5},
\end{gathered}
$$

where $Q_{\mathrm{ow}}$ is the outlet outflow, $C_{\mathrm{ow}}$ the outlet discharge coefficient, $A$ the outlet crosssectional area, $y$ the water level at a given simulation time, $y_{\mathrm{ow}}$ the outlet axis elevation, $Q_{\text {spill }}$ the spillway outflow, $C_{\text {spill }}$ the spillway discharge coefficient, $L$ the spillway length and $y_{\text {spill }}$ the spillway crest elevation. The next section presents the parameters adopted for each dam.

Finally, the routing in reservoirs affects the model time step, which is based on the Courant-Friedrichs-Levy condition, and is dependent on the largest simulated water depth in the basin. Then, differences in model bathymetry (e.g., by considering stage-volume relationships from different sources) may lead to changes in time step, which will be relatively small since the overall water depth will tend to remain similar.

\subsection{Model application in the Itajaí-Açu Basin}

Brazilian National Water Agency (ANA) daily observed precipitation data were used to force the model. For evapotranspiration computation with Penman-Monteith equation, Brazilian National Institute of Meteorology (INMET) long-term climatology data (wind speed, relative humidity, air temperature, sunlight hours) for the Indaial gauge were used (available at http://www.inmet.gov.br/portal/index.php?r=clima/normaisclimatologicas). 
A 1-m high-resolution DEM from Santa Catarina State's Secretary of Sustainable Economic Development (SDS, available at http://sigsc.sds.sc.gov.br/; estimated vertical accuracy of $0.39 \mathrm{~m}$ ) was used in this study, which was upscaled from $1 \mathrm{~m}$ spatial resolution to $30 \mathrm{~m}$ to allow efficient data management. This DEM was generated with aerophotogrammetry based on airborne images, and the higher quality of this product in comparison with the commonly used SRTM DEM was discussed by Speckhann et al. (2017) and Fleischmann et al. (2019).

The basin was discretized into 1118 unit-catchments and eight sub-basins. Following the methodology described by Pontes et al. (2017), the basin was further divided into eight sub-basins and a total of 11 hydrologic response units (HRUs) for the definition of soil and vegetation parameters. See "Appendix" for details on the rainfall-runoff module parameterization. The HRUs were obtained through a combination of soil type and land use maps available from the Santa Catarina State's EPAGRI/CIRAM database (available at http:// ciram.epagri.sc.gov.br/).

For hydrodynamic channel parameters, river bankfull width and depth values were adjusted to locally available data following hydraulic geometry relationships (Leopold and Maddock 1953):

$$
\begin{gathered}
W=0.95 * A_{\mathrm{d}}^{0.5} \\
H=0.3 * A_{\mathrm{d}}^{0.3}
\end{gathered}
$$

where $W$ is the bankfull width, $H$ is the bankfull depth and $A_{\mathrm{d}}$ is the drainage area. Manning's coefficient was set to 0.03 for the whole basin based on typical river values. Downstream boundary condition was set as a normal depth with a $10 \mathrm{~cm} / \mathrm{km}$ slope. For simplicity, tide effects were not considered in the downstream boundary.

The three reservoirs discussed in "Study Area" section were simulated as internal boundary conditions. Reservoir characteristics were obtained from Comitê do Itajaí (2010) and JICA (2011) and are summarized in Table 1. We adopted the original reservoirs for simulation, i.e., without the alterations made in 2015 in spillways and other structures. For model calibration, the reservoirs were considered during the period they were active (i.e.,

Table 1 Summary of characteristics of the three simulated reservoirs and the respective outflow hydraulic structures. Adapted from Comitê do Itajaí (2010) and Pinheiro and Frank (2003)

\begin{tabular}{llll}
\hline Characteristic & Itajaí do Sul dam & Itajaí do Oeste dam & Itajaí do Norte dam \\
\hline Spillway length (m) & 65 & 100 & 300 \\
Spillway crest elevation (m) & 399 & 360 & 302 \\
Spillway discharge coefficient & 2.0758 & 2.1658 & 2.0506 \\
Number of gates in bottom outlets & 5 & 7 & 2 \\
Area per gate $\left(\mathrm{m}^{2}\right)$ & 1.77 & 1.77 & 6.76 \\
Bottom outlet axis elevation (m) & 368 & 340.05 & 253 \\
Outlet discharge coefficient & 0.7 & 0.6667 & 0.89513 \\
Maximum volume (hm $\left.{ }^{3}\right)$ & 94 & 83 & 357 \\
Dam height (m) & 43.5 & 20 & 58.5 \\
Maximum water level (m) & 408 & 363 & 304.25 \\
Dam type & Rockfill dam & Concrete dam & Rockfill dam \\
First year of operation & 1975 & 1973 & 1992 \\
\hline
\end{tabular}


from 1973 on for Itajaí do Oeste dam, 1975 for Itajaí do Sul dam and 1993 for Itajaí do Norte dam). The dams' operation rules were set as simple ones, considering that all outflow structures gates were always open (i.e., a passive reservoir operation; Ayalew et al. 2013). This is reasonable given the low discharge capacity of the dams' structures. Furthermore, this is the typical operation of Itajaí do Norte dam. The adopted dam rating curves are presented in Fig. 3, considering the outlet works and spillways equations as provided by JICA (2011).

The model was run for the 1950-2016 period following rainfall data availability and was calibrated based on Nash-Sutcliffe efficiency (NSE) metric and a visual comparison between daily observed discharges and simulated flood frequency curves for the 11 gauges presented in Fig. 1. Flood frequency curves were computed by estimating empirical probabilities for maximum annual discharges with the Weibull plotting position formula. The long-term simulation bias metric was also assessed.

For evaluation of model structure and relative effects of reservoirs and floodplains on flood control at the basin scale, the following simulation scenarios were performed:

(a) Full model (with reservoirs and floodplains; default scenario used for calibration);

(b) Without reservoirs but with floodplains (i.e., the basin natural scenario);

(c) Without both reservoirs and floodplains (i.e., only rectangular channels throughout the basin).

For model calibration (Sect. 4.1), the reservoirs were only considered during the period they were already built. In turn, for the analysis of the relative role between reservoirs and floodplains on flood attenuation (Sects. 4.2, 4.3), the reservoirs were considered active during the whole period in order to assess the potential of the dams to mitigate floods in the whole 1950-2016 simulation period.

\section{Results}

\subsection{Model calibration}

The model was adjusted through calibration of rainfall-runoff model parameters (related essentially to runoff generation and soil water storage capacity), considering both reservoir
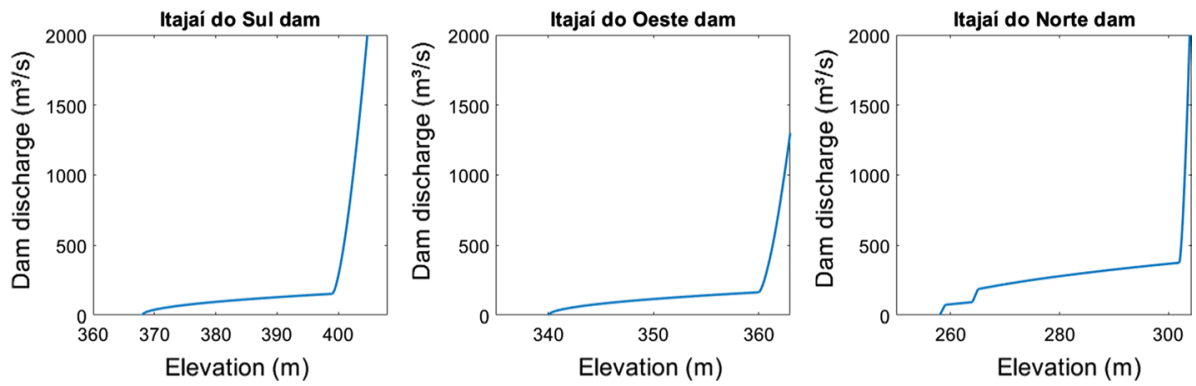

Fig. 3 Water level-discharge relationships for the Itajaí do Sul, Itajaí do Oeste and Itajaí do Norte dams. Adapted from JICA (2011) 
and floodplain hydrodynamics. Selected hydrographs at Taió (just downstream of the Itajaí do Oeste dam), Ituporanga (just downstream of the Itajaí do Sul dam) and Rio do Sul locations are presented in Fig. 4. The reservoirs' effects on hydrograph attenuation are evident, with a post-event release of the reservoir stored water (red lines), which is coincident with
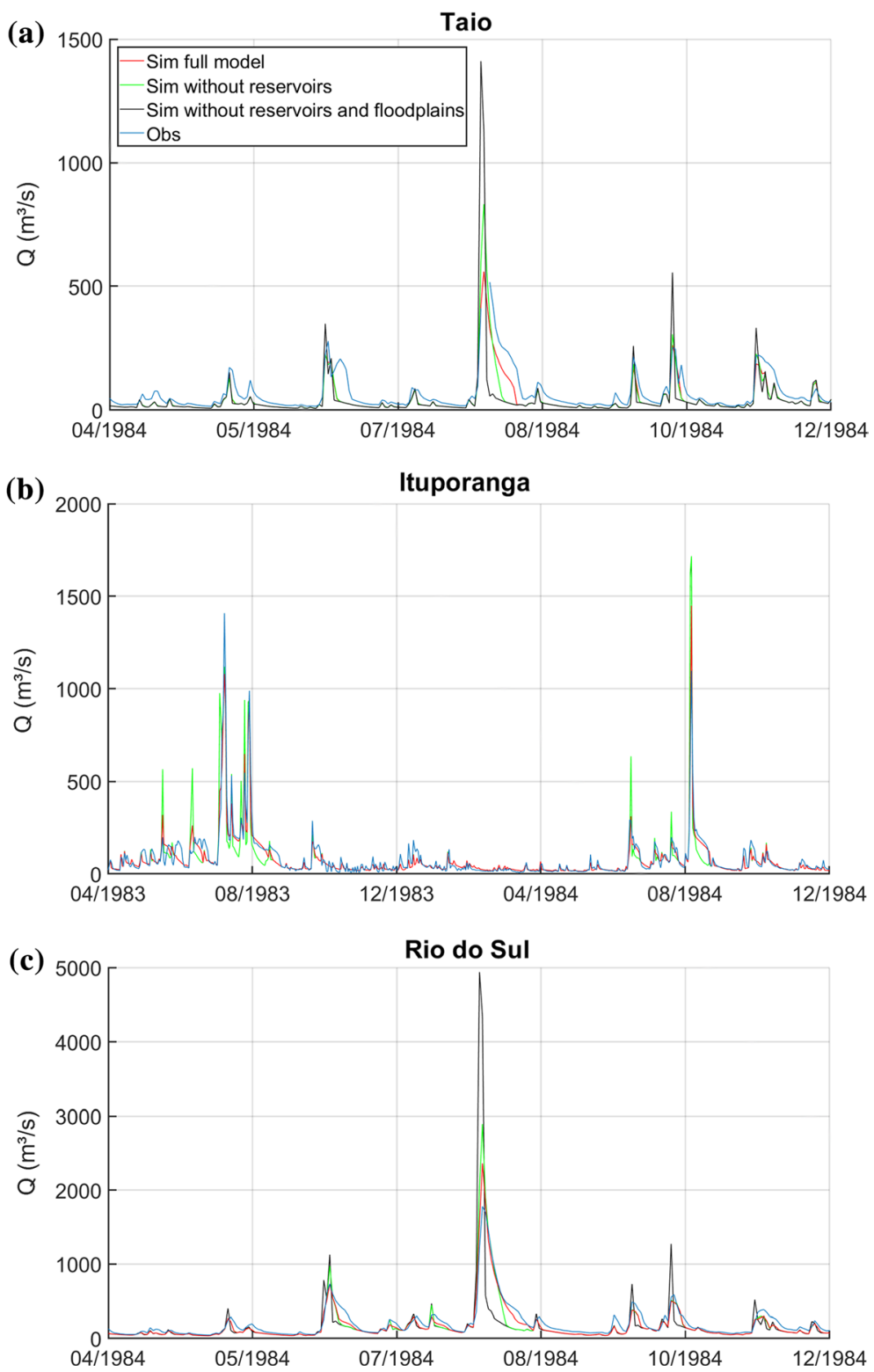

Fig. 4 Observed and simulated (scenarios full model, without reservoirs and without both reservoirs and floodplains) hydrographs in a Itajaí do Oeste River at Taió (just downstream of the Itajaí do Oeste dam), b Itajaí do Sul River at Ituporanga (just downstream of the Itajaí do Sul dam) and c Itajaí-Açu river at Rio do Sul location, for the 1984, 1983/1984 and 1984 floods, respectively 
observations (blue lines) in the three displayed hydrographs (see also the simulated dam outflow in Fig. 6). This can be compared with the simulations without reservoirs but with floodplains (green lines) and without both reservoirs and floodplains (black lines), which have higher peaks and faster recession limbs. The absence of floodplain attenuation leads to expressive discharge overestimation at Taió and Rio do Sul locations (black lines) in comparison with the other two scenarios. At Ituporanga gauge in Itajaí do Sul River, the relatively small floodplains led to similar simulated hydrographs between scenarios with and without floodplains (green and black lines).

Although the post-release event indicates a satisfactory model adjustment with the reservoir operations, some errors in peak discharge are observed, which may be explained by the uncertain observed precipitation data. Errors may also arise due to the simple adopted operation rule with all gates always open, while the Itajaí do Sul and Itajaí do Oeste are typically operated based on observed precipitation and discharges across the basin during a flood event.

NSE and bias metrics are given in Table 2 for the default simulation scenario (i.e., full model) and show the generally satisfactory agreement between observations and simulations in the default scenario, despite the basin complexity in terms of reservoir, floodplains and river hydrodynamics effects. Most gauges presented NSE higher than 0.65 and bias lower than $10 \%$. Large bias $(\sim 35 \%)$ in Blumenau may be related to erroneous low simulated flow values due to non-represented tide effects on the model downstream boundary condition.

NSE differences from the default scenario are also presented in Table 2 for the scenarios without reservoirs/floodplains, in order to understand the relative impact of representing these processes on hydrograph simulation. The default scenario presented highest NSE values among all gauges, except for those located upstream from reservoirs which did not present differences between scenarios (Barra do Prata, Timbó, Trombudo and Brusque). At Taió and Ituporanga, the evaluated gauges located closest to reservoirs, differences between scenarios with and without dams were the highest ( $\triangle \mathrm{NSE}$ of -0.13 and -0.18 , respectively). The role of floodplain seems to be even more relevant in certain locations,

Table 2 Model performance Nash-Sutcliffe efficiency (NSE) and bias metric for the default scenario (full model)

\begin{tabular}{lclll}
\hline Gauge name & $\begin{array}{l}\text { Full } \\
\text { model } \\
(\text { bias \%) }\end{array}$ & $\begin{array}{l}\text { Full } \\
\text { model } \\
(\mathrm{NSE})\end{array}$ & $\begin{array}{l}\text { No } \\
\text { reservoirs } \\
(\Delta \mathrm{NSE})\end{array}$ & $\begin{array}{l}\text { No reservoirs } \\
\text { No floodplains } \\
(\Delta \mathrm{NSE})\end{array}$ \\
\hline Taió & -19.4 & 0.70 & -0.13 & -0.89 \\
Ituporanga & -1.4 & 0.70 & -0.18 & -0.18 \\
Rio do Sul & -9.6 & 0.83 & -0.03 & -0.85 \\
Barra do Prata & 5.4 & 0.66 & 0.00 & 0.00 \\
Ibirama & -5.1 & 0.55 & -0.06 & -0.07 \\
Apiuna & -2.6 & 0.84 & -0.03 & -0.46 \\
Indaial & -18.2 & 0.78 & -0.01 & -0.32 \\
Timbó & -10.7 & 0.73 & 0.00 & -0.01 \\
Blumenau & -35.4 & 0.57 & -0.02 & -0.28 \\
Trombudo & 0.4 & 0.54 & 0.00 & -0.07 \\
Brusque & -12.3 & 0.65 & 0.00 & -0.01 \\
\hline
\end{tabular}

Differences from the full model NSE ( $\triangle$ NSE) are presented for the scenarios without reservoirs but with floodplains (No reservoirs) and without both reservoirs and floodplains (no reservoirs, no floodplains) 
with its absence expressively decreasing NSE from 0.70 to -0.19 in Taió $(\triangle \mathrm{NSE}=-0.89)$ and 0.57-0.29 in Blumenau ( $\triangle \mathrm{NSE}=-0.28$ ). It must be stressed here that the performance metrics are used for comparison among model structure scenarios only, and not to infer which is the best one, since parameter calibration for different structures can lead to different performance values.

Finally, the model was calibrated considering a compromise between simulated discharge and maximum values, as done by other studies (e.g., Paquet et al. 2013). Figure 5 presents flood frequency curves (maximum annual discharges) for the 11 gauges used for model adjustment. The curves reinforce the satisfactory model adjustment to extreme discharges. Disagreements in the very extreme events in Barra do Prata and Trombudo Central gauges are possibly related to erroneous observed precipitation.

\subsection{Site-specific analysis}

The relative role of reservoirs and floodplains on flood control in the Itajaí-Açu River Basin is investigated in this section for specific sites. Figure 6 presents the simulated time series of outflow discharges and water levels at the dam sites for the events of 1983 and 1984. Note that the Itajaí do Norte dam did not exist in 1983-1984 but was simulated here as a hypothetical scenario. With the simplified adopted operation rules, the level in the three reservoirs would exceed the spillway crest during the 1983 event and only in Itajaí do Sul dam during the 1984 event.

Flood frequency curves for different simulation scenarios (full model, without reservoirs, and without both reservoirs and floodplains) are presented in Fig. 7. The difference between red and green dots can be interpreted as the reservoir attenuation effect (plus synergic effects between reservoirs and floodplains), while the difference between green and black dots is the floodplain-related attenuation. There are major differences between the evaluated sites. While Taió presents a large difference between simulations with and without floodplains (green $\times$ black dots), Ituporanga and Ibirama cities in Itajaí do Sul and Itajaí do Norte rivers, respectively, show a negligible difference. This is explained because these
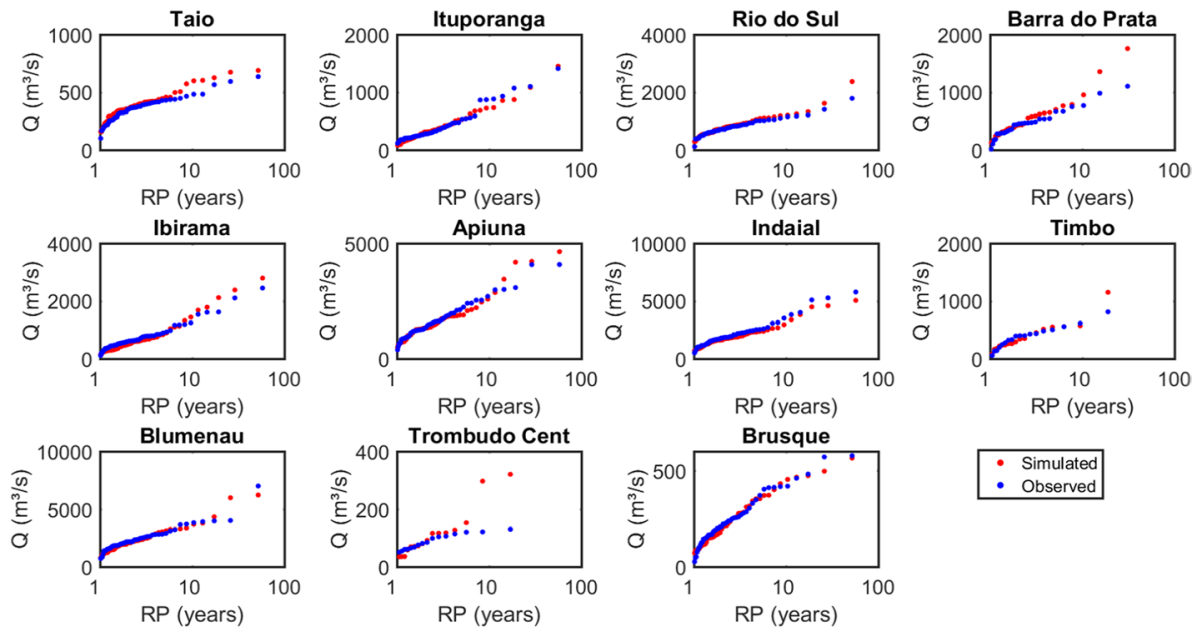

Fig. 5 Comparison between observed and simulated flood frequency curves (discharge x return period) for 11 gauges as displayed in Fig. 1 

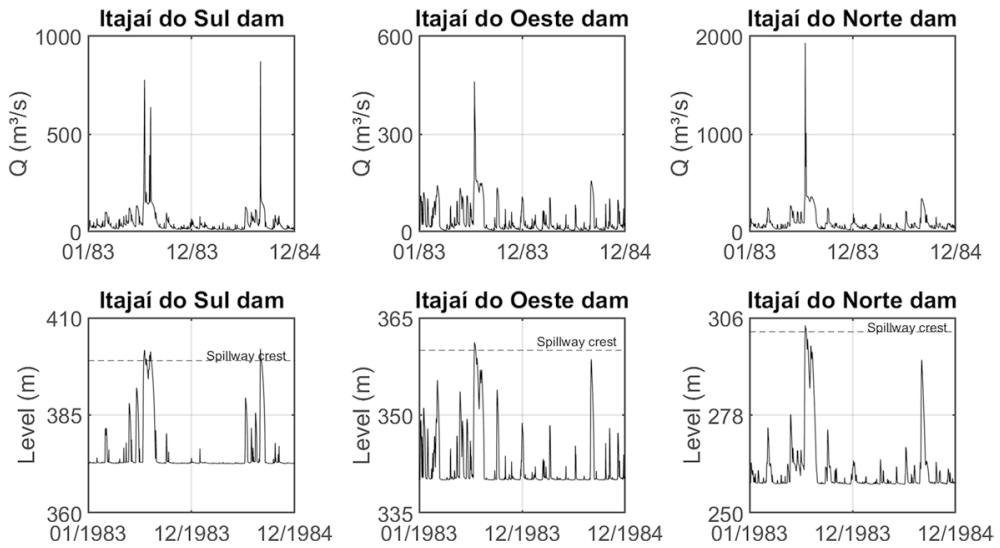

Fig. 6 Simulated time series of dam outflow discharge and water level for the period 1983-1984. Note that the Itajaí do Norte dam did not exist in 1983 but was simulated here as a hypothetical scenario
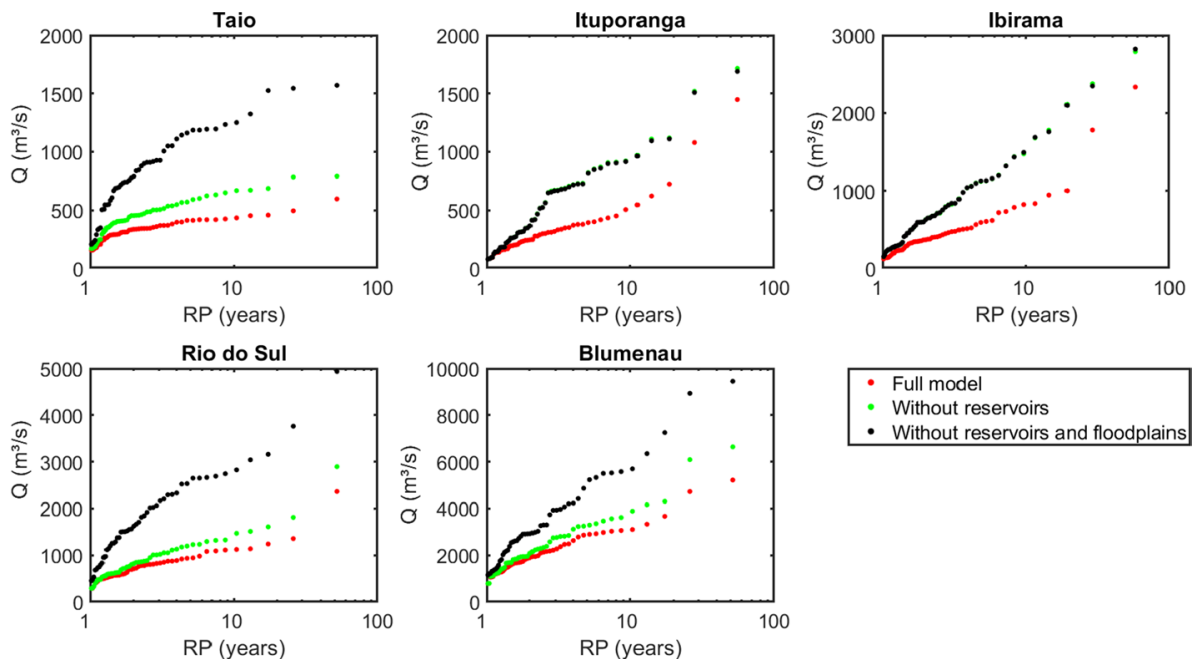

- Full model

Without reservoirs

- Without reservoirs and floodplains

Fig. 7 Comparison between flood frequency curves (discharge $\mathrm{x}$ return period) for three simulation scenarios: (i) full model (red), (ii) without reservoirs but with floodplains (green) and (iii) without both floodplains and reservoirs (black), for five selected locations throughout the basin (Fig. 1)

two locations have relatively small floodplain areas on their upstream basin. The floodplain effects in Taió can be also seen in its flatter flood frequency curve in relation to Ituporanga and Ibirama locations.

Looking at more downstream locations, Rio do Sul and Blumenau cities along the Itajaí-Açu mainstem also present major floodplain-related attenuation, due to floodplains located both along the Itajaí do Sul River and the Itajaí-Açu mainstem itself. More interestingly, results show that floodplain storage provides more important effects on flood mitigation along the basin (except for the Itajaí do Oeste and Itajaí do Sul tributaries) than the flood control reservoirs. For example, the 10-year flood (one must 
notice the uncertainty in empirically defining a 10-year flood from a 66-year-long simulation period) would be reduced from $2824 \mathrm{~m}^{3} / \mathrm{s}\left(5694 \mathrm{~m}^{3} / \mathrm{s}\right)$ to $1470 \mathrm{~m}^{3} / \mathrm{s}\left(3883 \mathrm{~m}^{3} / \mathrm{s}\right)$ due to floodplains and from $1470 \mathrm{~m}^{3} / \mathrm{s}\left(3883 \mathrm{~m}^{3} / \mathrm{s}\right)$ to $1124 \mathrm{~m}^{3} / \mathrm{s}\left(3102 \mathrm{~m}^{3} / \mathrm{s}\right)$ due to reservoir operation in Rio do Sul (Blumenau), respectively.

Looking at the whole 1950-2016 simulation period at specific sites, Fig. 8 presents flood peak reduction for each year maximum flood. Reduction values are related to a scenario without reservoirs and floodplains. Then, for a 10-year flood in Taió, there would be a peak reduction of $43 \%$ due to floodplains and $61 \%$ due to the synergic effects of floodplains and reservoirs. Thus, an $18 \%$ reduction from the scenario without floodplains and reservoirs could be attributed to reservoirs (plus synergic effects between reservoirs and floodplains). Total peak reductions in Taió, Ituporanga and Ibirama, located relatively close to the dams, reach values as high as 60-70\%. Floodplain effects in Ibirama and Ituporanga (i.e., Itajaí do Norte and Itajaí do Sul rivers) are negligible, as also seen in the flood frequency curves in Fig. 7, but are responsible for reductions as high as $60 \%$ in Taió and Rio do Sul cities. Regarding reservoirs, in Taió and Ituporanga there is a maximum reservoir peak reduction for events between 5 and 15 years. For more extreme events, smaller attenuation is expected due to the increasing flood volume. Obviously, these conclusions are dependent on the adopted operation rule. These results are in agreement with Pinheiro and Frank (2003), who simulated these reservoirs and estimated a $20 \%(12 \%)$ peak reduction for a 25 -year (100-year) flood event in the Itajaí river at Rio do Sul.

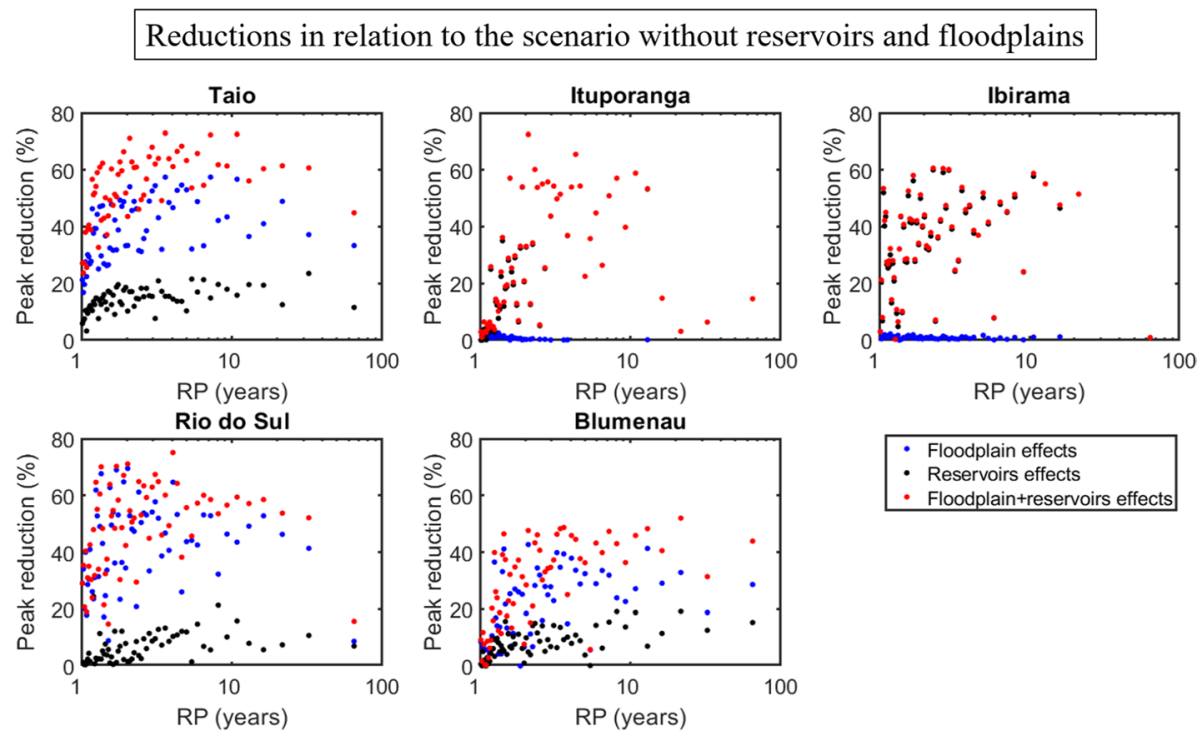

Fig. 8 Relationship between peak discharge reduction and flood frequency (return period) for five selected locations throughout the basin due to floodplains (blue), the combined effects of reservoirs and floodplains (red) and reservoirs (black; computed as the difference between red and blue dots). Peak reduction values (\%) are related to a scenario without both reservoirs and floodplains. Reservoirs' values also include synergic effects between floodplains and reservoirs 


\subsection{Basin-scale analysis}

Tightly coupling a hydrodynamic model to a hydrologic one enables a basin-wide evaluation of attenuation effects by reservoirs and floodplains. Figure 9 shows, for each unitcatchment in the basin in terms of its respective upstream drainage area, the alteration on maximum water level and peak discharge due to these factors. Results are presented for the simulated 1984 extreme flood event, which was the largest simulated event in the 1950-2016 period at Ituporanga and Rio do Sul locations.

The highest discharge and water level attenuations occur around the dams' locations, with the highest reduction obtained for the Itajaí do Norte dam $(75 \%$ and $6 \mathrm{~m})$, followed by Itajaí do Oeste $(55 \%$ and $2 \mathrm{~m})$ and Itajaí do Sul $(18 \%$ and $1 \mathrm{~m})$ dams, and decrease in the downstream direction. It must be noticed that these conclusions are related to the 1984 flood and are dependent on the adopted operation rules. The 1984 year was the most extreme in Itajaí do Sul River, which explains the lowest reduction in its respective dam. On the other hand, as concluded in the previous section, floodplains have a major role on attenuating floods all over the basin, reaching water level reductions as high as $20 \mathrm{~m}$ and discharge attenuation of more than $50 \%$ in comparison to a scenario where all channels are rectangular (i.e., scenario without floodplains and reservoirs).

There is a general trend of decreasing flood reduction (for both discharges and water levels) due to reservoirs with increasing basin drainage area (red dots in Fig. 9). This is expected due to lateral inflows that contribute to the basin hydrograph in the downstream parts and lower the peak reduction effect by upstream reservoirs. For floodplains (blue dots), this trend was not so clear, since it depends on local geomorphological features. In the Itajaí-Açu River Basin, reaches with floodplain terraces alternate with incised valley reaches. In the most downstream reaches, near Itajaí city, the highest floodplain effects are observed (up to $80 \%$ peak discharge reduction), although reservoirs also play an important role in mitigating floods. Finally, it is important to notice that even reaches that are not directly downstream from a given dam may have their water level reduced in the scenarios
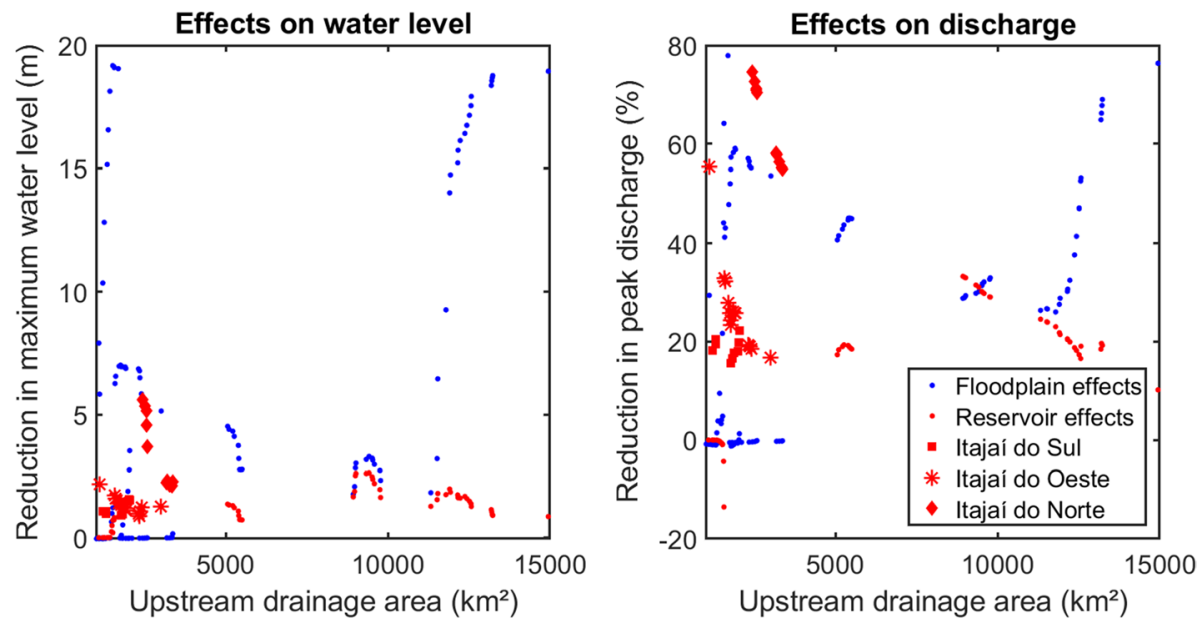

Fig. 9 Basin-wide evaluation of reduction in maximum water level (m) and peak discharge (\%) due to reservoirs and floodplains, in relation to upstream drainage area, for the 1984 event. Each point relates to a unitcatchment, and those related to the three main tributaries with reservoirs are highlighted with different red symbols. Results only plotted for drainage area $>1000 \mathrm{~km}^{2}$ to improve readability 
with reservoirs due to backwater effects from the mainstem. This does not occur in simpler routing methods such as Muskingum-Cunge.

Maximum water depth maps for scenarios with and without dams are presented for the whole Itajaí-Açu basin in Fig. 10. Water depths are computed based on the HAND map (see Sect. 3.3) and the simulated HAND value within each unit-catchment. The maximum water level of each unit-catchment in the whole 1950-2016 simulation period is used for the mapping. Figure 10a presents results for the full model scenario, and it clearly shows the deep waters along the three reservoirs and the maximum simulated extent of each reservoir. It can be also seen the large floodable areas in the Itajaí do Oeste region and along the confluence of Itajaí do Oeste and Itajaí do Sul rivers, near the city of Rio do Sul (see Fig. 1 for city locations). In the tributaries of Itajaí do Oeste river, important rice crops exist along the floodplains. Also, a large flooding is expected to occur around Itajaí city close to the Itajaí-Açu River mouth in the Atlantic Ocean, although this result is highly dependent on the adopted downstream boundary condition (a constant water slope in this study), which ideally should also include tide effects.

Figure 10b shows flood maps in the scenario without reservoirs, while Fig. 10c presents the difference between a and $b$ of Fig. 10, i.e., the dam effects on maximum water depth. The dams decrease water depths during flooding across the whole basin in a range between 0 and $3 \mathrm{~m}$ in major floodable areas such as Rio do Sul and Itajaí cities, Itajaí do Oeste River, Lower Itajaí do Sul River and the Lower Itajaí-Açu in general. Large water depth decreases $(\sim 3 \mathrm{~m})$ occur in the Middle Itajaí-Açu river, which presents relatively incised valleys. The presence of reservoirs also considerably increases water depths (up to $40 \mathrm{~m}$ ) in the reaches upstream from the dams' locations.

\section{Discussion: toward large-scale coupling of hydrodynamics, hydrology and reservoir effects}

Large-scale hydrologic-hydrodynamic models are powerful tools for analyzing flood mitigation structures, and these models are now a reality. Many applications in this context have been recently presented in the literature for flood hazard mapping and flood forecasting, but not for flood control reservoirs. In this study, we present the application of MGB model in the Itajaí-Açu River Basin in Brazil $\left(\sim 15,000 \mathrm{~km}^{2}\right)$ with an explicit representation of reservoir hydrodynamics as an internal boundary condition within the simulated drainage network. The modeling approach involved replacing the momentum equation of the inertial routing method at each dam location by the respective dam outflow equations (spillways and outlets works). It allows a more correct representation of backwater and other hydrodynamic effects (e.g., flood wave diffusion) across the reservoir tributaries in comparison with lumped reservoir simulations within rainfall-runoff models. The reservoirs' bathymetry was represented in the adopted DEM since they were practically empty during the DEM creation. The model uses an online coupling between hydrologic and hydrodynamic processes, by, for example, considering at each time step which fraction of each unit-catchment is covered by water (e.g., flooded floodplain or reservoir lake) and open soil/vegetation (Fleischmann et al. 2018). As a result, the model is capable of simulating hydrodynamic processes in reaches that are affected by reservoir flood control and floodplain attenuation all over the basin.

The model was manually calibrated by considering a compromise between simulated hydrographs (NSE) and flood frequency curves. It was calibrated considering both floodplain and reservoir attenuation effects, and the results were considered satisfactory. Lower NSE values were obtained for scenarios without floodplains and reservoirs. Although a different 

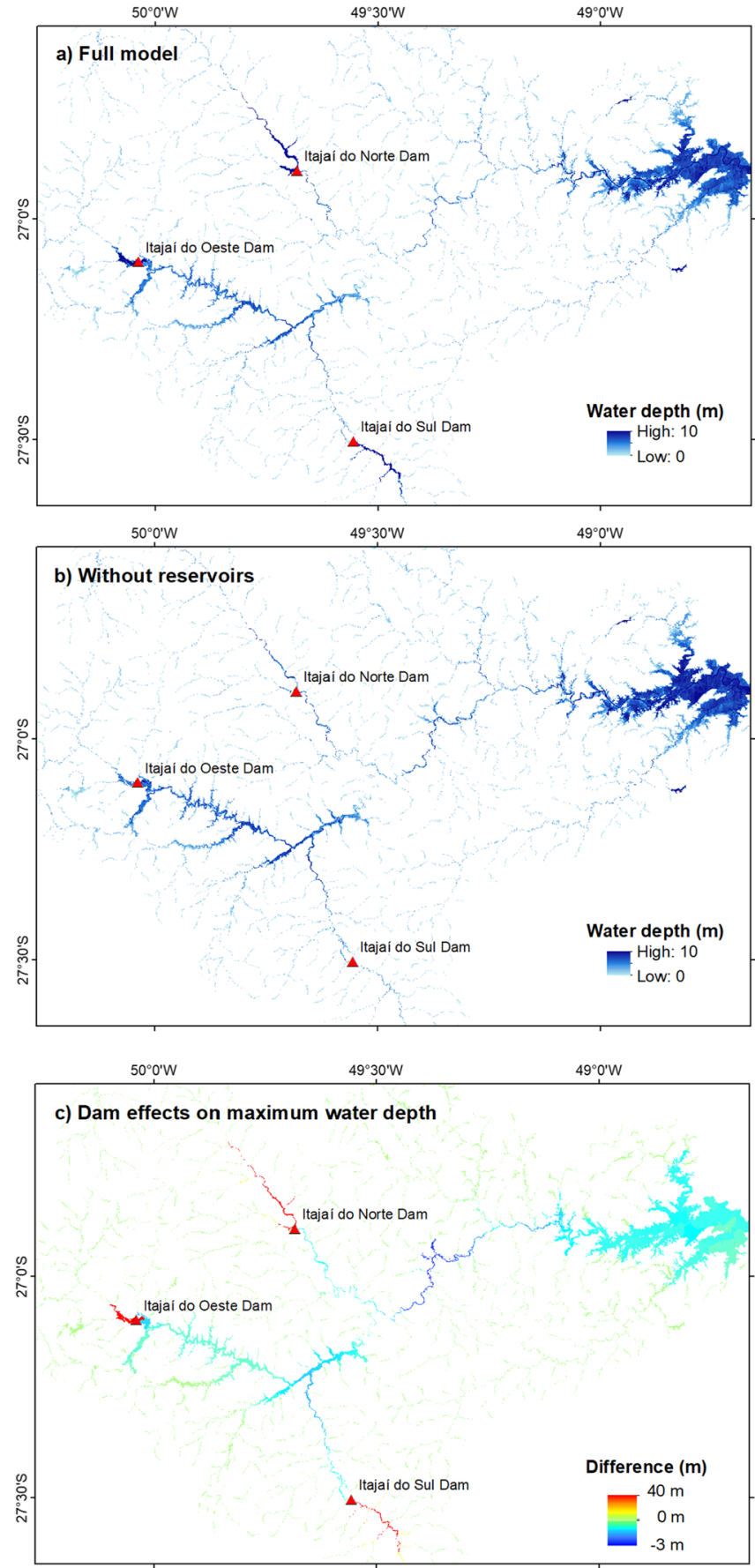

Fig. 10 Maximum water depth and flood extent in the scenarios $\mathbf{a}$ default and $\mathbf{b}$ without reservoirs. $\mathbf{c}$ Difference between scenarios $(\mathbf{a}, \mathbf{b})$, i.e., the effects of the three dams on maximum water depth. Positive (negative) values indicate an increase (decrease) in maximum water depth 
calibration strategy (e.g., by calibrating model parameters in the scenario without reservoirs and floodplains) could yield different results (e.g., better NSE values for the scenario without reservoirs and floodplains), with this analysis we stress the strong differences that occur basinwide in terms of simulation performance due to representation of reservoirs and floodplains, suggesting their important role in improving model results. With such results, we highlight the need of making parameter calibration right "for the right reasons" (Kirchner 2006).

We presented some interesting results on the Itajaí-Açu River Basin flood dynamics and on the relative role of floodplains and reservoirs on attenuating floods. Firstly, we showed how Itajaí do Oeste River and Itajaí-Açu mainstem have important floodplain effects, which are responsible for larger flood attenuation than the reservoirs themselves. This highlights the importance of preserving floodplain storage for flood control. The other two main tributaries, Itajaí do Sul and Itajaí do Norte, do not present extensive floodplains, and practically all flood attenuation is due to the existing flood control dams. As expected, the three existing flood control dams in the basin lead to major flood peak attenuation along the basin, with the Itajaí do Norte dam leading to the highest discharge and water level reductions, up to $75 \%$ of peak reduction in the 1984 event in locations close to the dam. By looking at multiple locations across the basin, the long-term simulation (1950-2016 period) showed that the three dams (especially Itajaí do Sul and Itajaí do Oeste dams), under the adopted operation rules, are more effective to reduce 5- to 15-year floods, having smaller capacity to deal with larger floods. The model developed in this study would be very useful for improving dams' operation rules to foster flood mitigation basin-wide. On the other hand, our results are subjected to important uncertainties as operation rule and hydraulic structure coefficients, which would benefit from more locally based information. However, the actual operation rule is very difficult to define since it is based on local authorities' decisions. The assumption of the bottom outlet gates always open is considered reasonable given their low discharge capacity. Similar operation rules have also been used in consultancy projects on the subject of flood defense structures in this basin. We then deem these assumptions reasonably satisfactory to simulate the reservoirs dynamics, especially considering poorly gauged structures as the Itajaí-Açu dams.

The adopted methodology to simulate reservoirs could be adapted for other dams worldwide. The two main data inputs refer to the reservoir level-storage relationship and the dam outflow equations (i.e., spillway equations, gates operation rules, etc.), which can be simplified to simulate reservoirs without in situ data. Simplified operation rules have been proposed by recent studies with regional/global hydrologic models (Hanasaki et al. 2006; Döll et al. 2009; Zajac et al. 2017), considering, for example, the reservoir storage and water demands. For estimating reservoir storage (or bathymetry), remote sensing data processing is very promising (Gao et al. 2012; Rodrigues et al. 2012; Duan and Bastiaanssen 2013; Zhang et al. 2014; Bonnema et al. 2016; Avisse et al. 2017; Bonnema and Hossain 2019), for instance, by combining surface water from optical imagery and water level from satellite altimetry. New global datasets and methods describing reservoirs and elevation-area-volume relationships present also interesting opportunities for future developments (Lehner et al. 2011; Gao et al. 2012; Yigzaw et al. 2018). In this study, we used prior knowledge of the reservoir hydraulic structures to run the model, as done by other researchers (e.g., Mateo et al. (2014)). Reservoirs that were built after the DEM survey can be simulated directly with the current MGB structure. For those that already existed during the DEM construction, the storage of the unit-catchments located along the reservoir lake should be corrected by the actual reservoir storage. This could be performed by, for example, replacing the DEM along the reservoir lake with the respective bathymetry. Alternatively, one could replace the DEM-derived elevation-volume relationship by the reservoir 
observed one, dividing the storage (equally or with other distribution patterns) among all unit-catchments.

It is important to notice, on the other hand, that in our model application the reservoirs were simulated in 1D dimension, which we expect to better represent river hydrodynamics and backwater effects along the lake. However, it is known that in many cases 2D or 3D fluxes are relevant, often associated with thermal stratification. In these cases, a further model refinement could be implemented, and in the specific case of 2D fluxes, the inertial equations could be considered, since they have been successfully applied for the simulation of some shallow lakes with the LISFLOOD-FP (e.g., Neal et al. (2012); Rudorff et al. (2014)) and MGB (Lopes et al. 2018) models. Some researchers have also coupled 1D river models to 2D lake models (Dargahi and Setegn 2011; Li et al. 2014; Zhang et al. 2017; Lopes et al. 2018; Munar et al. 2018; Tanaka et al. 2018), or even to 3D ones (Wu et al. 2017).

A coupled hydrologic-hydrodynamic model as presented here could bring many benefits for integrated water resources management. Firstly, it could be used to estimate flood frequency curves and probable maximum floods in scenarios with and without floodplains and reservoirs, which is fundamental to the understanding of flood risk changes (Ayalew et al. 2013; Felder et al. 2017; Tanaka et al. 2017; Gao et al. 2019; Su and Chen 2019). It also enables the evaluation of basin-scale effects of multiple reservoirs, e.g., for the assessment of coordinated operation of a cascade of reservoirs at both local and regional scales (e.g., Seibert et al. (2014)), together with flood attenuation by floodplains both upstream and downstream from the dams.

Finally, flood control structural measures as reservoirs are very relevant for many situations, although non-structural measures are being increasingly preferable (Green et al. 2000; Barraqué 2017), and dams with flood control only purpose are generally not built for large basins due to the required dam size to control very high flood volumes. Even then, there is an increasing need of improving our modeling capability of basin-scale effects associated with structural measures in the context of socio-hydrology (Di Baldassarre et al. 2018). On the other hand, hydroelectric reservoirs are being increasingly planned in many major rivers worldwide (Nilsson et al. 2005; Latrubesse et al. 2017), and the model approach presented in this study could be satisfactorily applied to evaluate basin hydrologic regime alterations in such situations.

\section{Conclusion}

In this study, we presented one of the first coupled hydrologic-hydrodynamic models of a large basin with simulation of reservoirs' hydrodynamics. We applied the MGB model to the Itajaí-Açu River Basin in Brazil $\left(15,000 \mathrm{~km}^{2}\right)$ and adapted it to simulate the three existing flood control dams. Our results showed that:

- It is feasible to represent reservoir 1D hydrodynamics within a large-scale $1 \mathrm{D}$ hydrologic-hydrodynamic model as an internal boundary condition by simply replacing the momentum equation by the dam outflow equation;

- Comparisons between scenarios with and without reservoirs and floodplains indicated the relative role of each process on attenuating floods throughout the basin;

- In the Itajaí-Açu River Basin, natural floodplains have a relevant role on flood mitigation for a large range of maximum floods, which may be more important than the flood control reservoirs' in certain floodplain regulated reaches (e.g., Itajaí do Oeste river and Itajaí-Açu mainstem); 
- The model rainfall-runoff parameters were manually calibrated by optimizing simulated hydrographs and flood frequency curves and indicated the necessity of considering floodplains and reservoirs during calibration to avoid overparameterized models;

- The proposed modeling framework is very interesting for basin-scale flood management, allowing, for example, the creation of basin-scale water depth maps and distributed estimates due to the building of reservoirs and thus improving the understanding of flood dynamics in complex basins with floodplains and reservoirs.

Acknowledgements The first author thanks the Brazilian CNPq (Conselho Nacional de Desenvolvimento Científico e Tecnológico) for supporting this research under the Grant Number 141161/2017-5.

\section{Appendix}

The MGB hydrologic-hydrodynamic model can be divided into two main modules: the rainfall-runoff (i.e., vertical hydrologic balance) and the flood wave routing (i.e., the inertial method). While the flood wave routing parameters were described in the main paper Sects. 3.2 and 3.3, the adopted rainfall-runoff parameters are described in this Appendix. Within the model, the basin is divided into unit-catchments, Hydrologic response units (HRUs) based on soil and land use types, and sub-basins.

The Itajaí-Açu River Basin was discretized into 1118 unit-catchments (Fig. 11), 11 HRU's (Fig. 12) and eight sub-basins (Fig. 13; based on major tributaries). The HRUs were

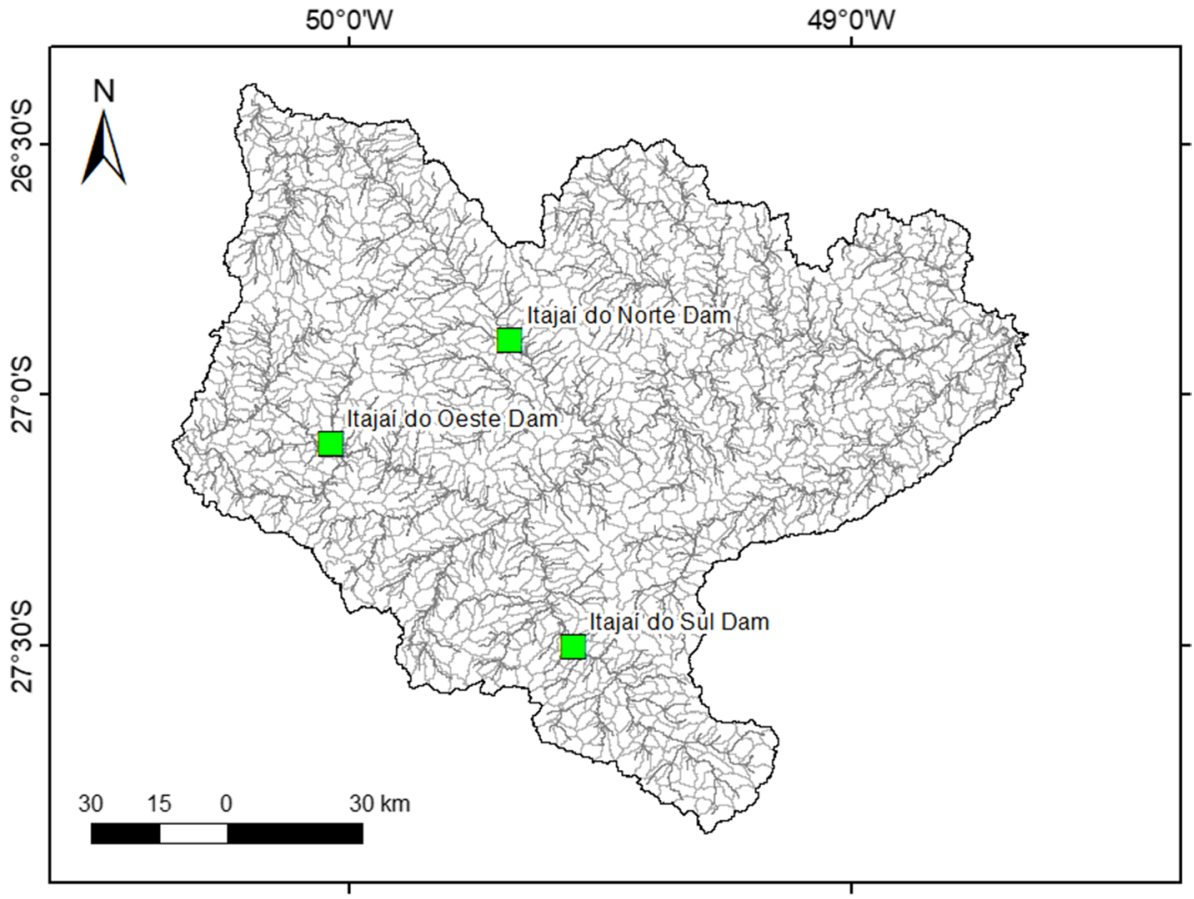

Fig. 11 Discretization of the Itajaí-Açu River Basin into 1118 unit-catchments (gray polygons) 


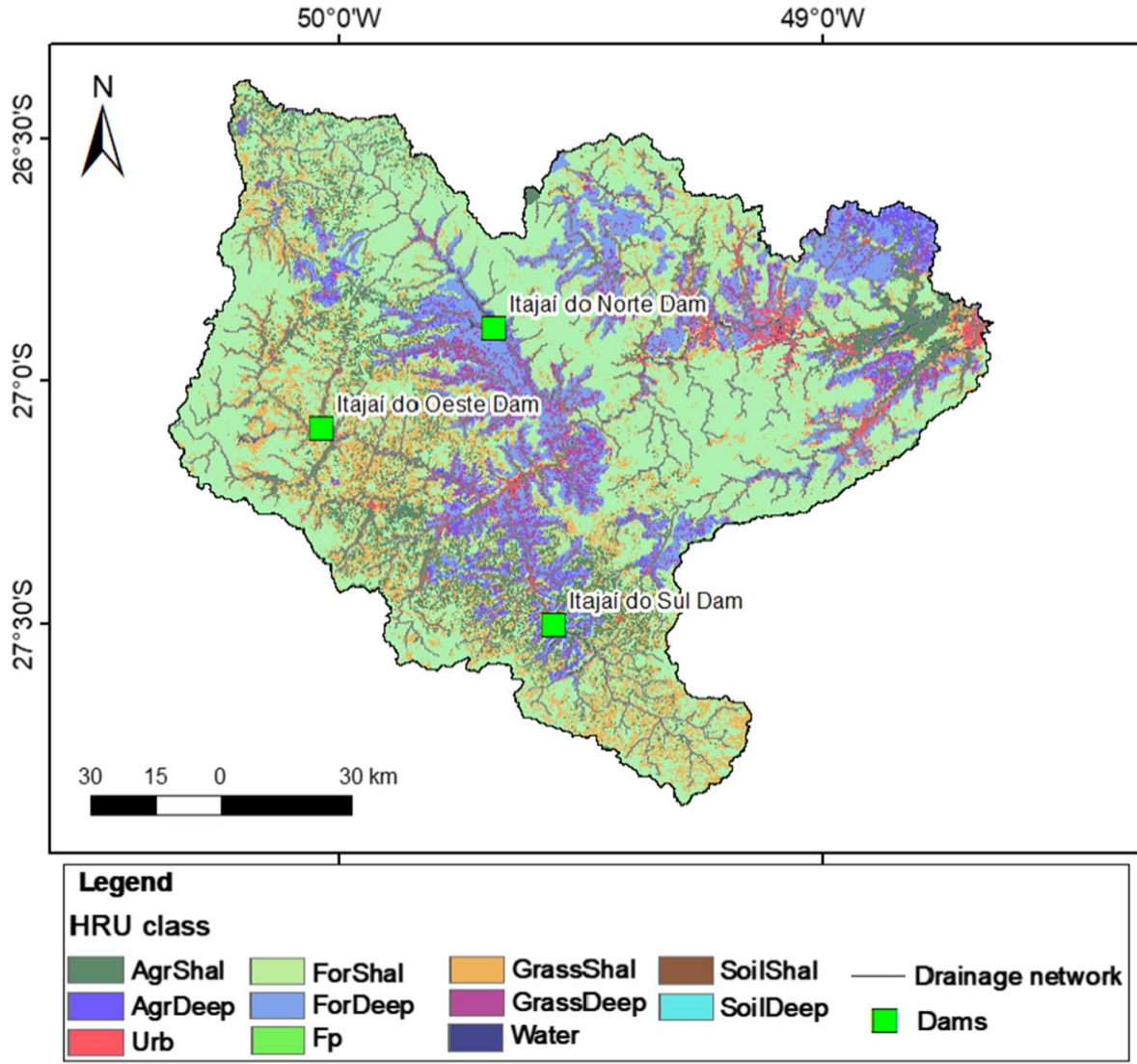

Fig. 12 Hydrologic response units used for model parameterization: agriculture with shallow soil (AgrShal), agriculture with deep soil (AgrDeep), forest with shallow soil (ForShal), forest with deep soil (ForDeep), grasslands with shallow soil (GrassShal), grasslands with deep soil (GrassDeep), shallow, bare soil (SoilShal), deep, bare soil (SoilDeep), urban areas (Urb), floodplains (Fp) and open water (Water)

obtained through a combination of soil type and land use maps available from the Santa Catarina State's EPAGRI/CIRAM database (available at http://ciram.epagri.sc.gov.br/).

For the model soil parameters $\mathrm{Wm}, \mathrm{b}$, Kbas and Kint, one parameter value is applied to a HRU within a sub-basin, and for the soil parameters $\mathrm{Cs}, \mathrm{Ci}$ and $\mathrm{Cb}$ (related to linear reservoirs, i.e., hillslope routing), the same value is applied for a whole sub-basin. Table 3 presents the calibrated soil parameters for each sub-basin. 


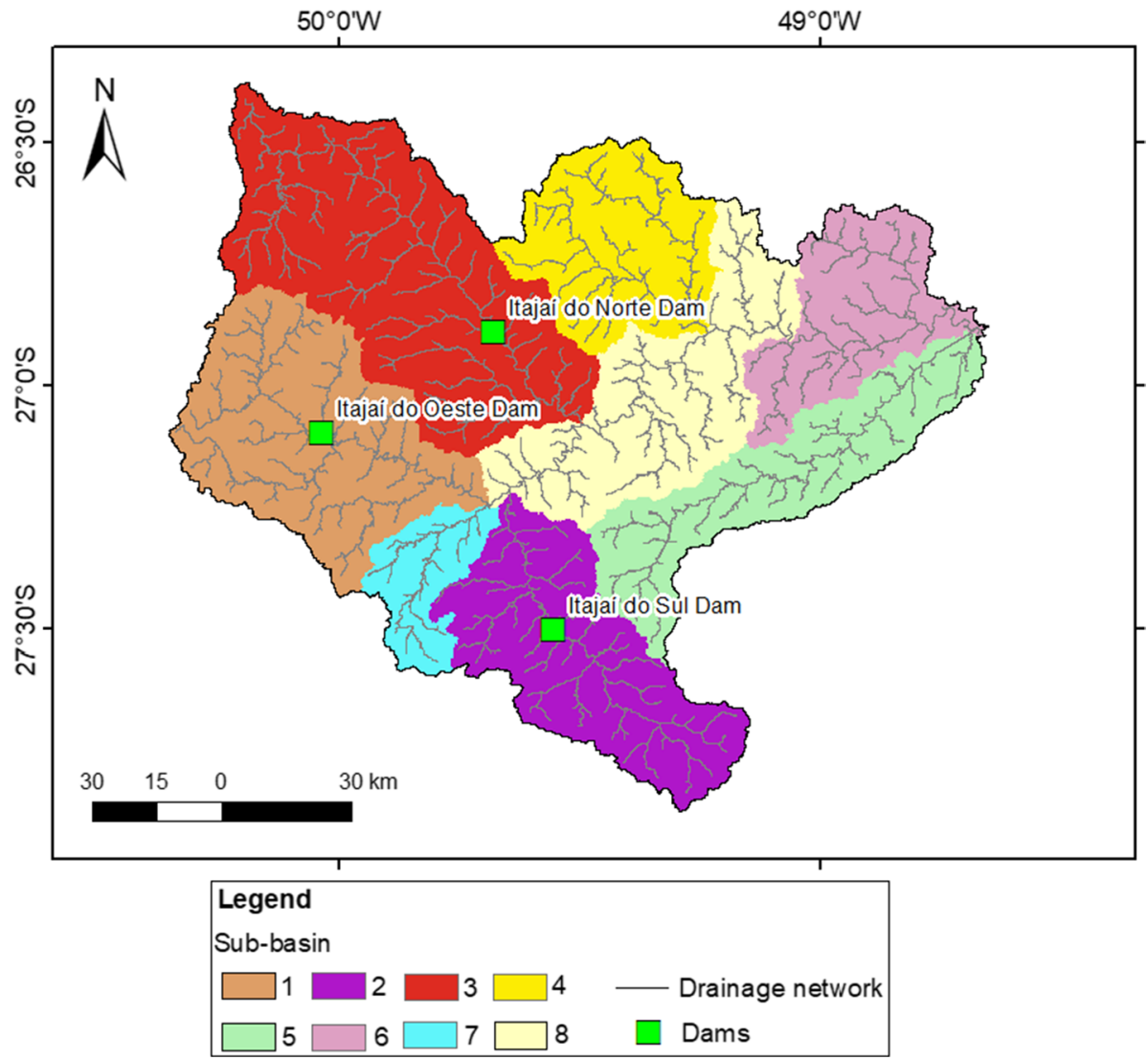

Fig. 13 Discretization of the Itajaí-Açu River Basin into eight sub-basins for model calibration

The values of vegetation parameters used for evapotranspiration and canopy interception are as follows. For albedo, values of $0.2,0.15,0.2$ and 0.3 were adopted for agriculture, forest, grasslands and bare soils, respectively. For leaf area index, values of 2, 6, 2 and $1 \mathrm{~m}^{2} / \mathrm{m}^{2}$ were adopted for agriculture, forest, grasslands and bare soils, respectively. For vegetation height, a value of $15 \mathrm{~m}$ was adopted for forest and $1 \mathrm{~m}$ for the remaining HRUs. Penman-Monteith surface resistance parameter value was adopted as $80 \mathrm{~s} / \mathrm{m}$ for all HRU's.

Please see Collischonn et al. (2007) for a thorough description of the model parameters. 
Table 3 Soil parameter values calibrated for the MGB model application in the Itajaí-Açu River Basin

\begin{tabular}{|c|c|c|c|c|}
\hline \multirow[t]{2}{*}{ HRU } & \multicolumn{4}{|l|}{ Parameters } \\
\hline & $\mathrm{Wm}(\mathrm{mm})$ & $\mathrm{b}(-)$ & $\mathrm{Kbas}(\mathrm{mm} / \mathrm{d})$ & $\operatorname{Kint}(\mathrm{mm} / \mathrm{d})$ \\
\hline \multicolumn{5}{|l|}{ Sub-basin 1} \\
\hline AgrShal & 50 & 0.1 & 0.5 & 5 \\
\hline AgrDeep & 150 & 0.1 & 0.5 & 5 \\
\hline ForShal & 50 & 0.1 & 0.5 & 5 \\
\hline ForDeep & 150 & 0.1 & 0.5 & 5 \\
\hline GrassShal & 250 & 0.1 & 0.5 & 5 \\
\hline GrassDeep & 50 & 0.1 & 0.5 & 5 \\
\hline SoilShal & 150 & 0.1 & 0.5 & 5 \\
\hline SoilDeep & 50 & 0.1 & 0.5 & 5 \\
\hline Urb & 150 & 0.1 & 0.5 & 5 \\
\hline $\mathrm{Fp}$ & 50 & 0.1 & 0.5 & 5 \\
\hline Water & 50 & 0.1 & 0.5 & 5 \\
\hline CS & 10 & & & \\
\hline CI & 100 & & & \\
\hline $\mathrm{CB}$ & 1000 & & & \\
\hline \multicolumn{5}{|l|}{ Sub-basin 2} \\
\hline AgrShal & 200 & 0.1 & 1 & 10 \\
\hline AgrDeep & 300 & 0.1 & 1 & 10 \\
\hline ForShal & 200 & 0.1 & 1 & 10 \\
\hline ForDeep & 200 & 0.1 & 1 & 10 \\
\hline GrassShal & 300 & 0.1 & 1 & 10 \\
\hline GrassDeep & 200 & 0.1 & 1 & 10 \\
\hline SoilShal & 300 & 0.1 & 1 & 10 \\
\hline SoilDeep & 200 & 0.1 & 1 & 10 \\
\hline Urb & 300 & 0.1 & 1 & 10 \\
\hline $\mathrm{Fp}$ & 200 & 0.1 & 1 & 10 \\
\hline Water & 200 & 0.1 & 1 & 10 \\
\hline $\mathrm{CS}$ & 10 & & & \\
\hline $\mathrm{CI}$ & 100 & & & \\
\hline $\mathrm{CB}$ & 1000 & & & \\
\hline \multicolumn{5}{|l|}{ Sub-basin 3} \\
\hline AgrShal & 200 & 0.1 & 0.1 & 5 \\
\hline AgrDeep & 400 & 0.1 & 0.1 & 5 \\
\hline ForShal & 200 & 0.1 & 0.1 & 5 \\
\hline ForDeep & 500 & 0.1 & 0.1 & 5 \\
\hline GrassShal & 700 & 0.1 & 0.1 & 5 \\
\hline GrassDeep & 200 & 0.1 & 0.1 & 5 \\
\hline SoilShal & 400 & 0.1 & 0.1 & 5 \\
\hline SoilDeep & 200 & 0.1 & 0.1 & 5 \\
\hline Urb & 400 & 0.1 & 0.1 & 5 \\
\hline $\mathrm{Fp}$ & 50 & 0.1 & 0.1 & 5 \\
\hline Water & 50 & 0.1 & 0.1 & 5 \\
\hline $\mathrm{CS}$ & 10 & & & \\
\hline CI & 80 & & & \\
\hline
\end{tabular}


Table 3 (continued)

\begin{tabular}{|c|c|c|c|c|}
\hline \multirow[t]{2}{*}{ HRU } & \multicolumn{4}{|l|}{ Parameters } \\
\hline & $\mathrm{Wm}(\mathrm{mm})$ & $\mathrm{b}(-)$ & $\operatorname{Kbas}(\mathrm{mm} / \mathrm{d})$ & $\operatorname{Kint}(\mathrm{mm} / \mathrm{d})$ \\
\hline $\mathrm{CB}$ & 1000 & & & \\
\hline \multicolumn{5}{|l|}{ Sub-basin 4} \\
\hline AgrShal & 200 & 0.15 & 1 & 10 \\
\hline AgrDeep & 400 & 0.15 & 1 & 10 \\
\hline ForShal & 200 & 0.15 & 1 & 10 \\
\hline ForDeep & 300 & 0.15 & 1 & 10 \\
\hline GrassShal & 400 & 0.15 & 1 & 10 \\
\hline GrassDeep & 200 & 0.15 & 1 & 10 \\
\hline SoilShal & 400 & 0.15 & 1 & 10 \\
\hline SoilDeep & 200 & 0.15 & 1 & 10 \\
\hline Urb & 400 & 0.15 & 1 & 10 \\
\hline $\mathrm{Fp}$ & 100 & 0.15 & 1 & 10 \\
\hline Water & 100 & 0.15 & 1 & 10 \\
\hline $\mathrm{CS}$ & 10 & & & \\
\hline CI & 100 & & & \\
\hline $\mathrm{CB}$ & 1000 & & & \\
\hline \multicolumn{5}{|l|}{ Sub-basin 5} \\
\hline AgrShal & 180 & 0.15 & 1 & 10 \\
\hline AgrDeep & 380 & 0.15 & 1 & 10 \\
\hline ForShal & 180 & 0.15 & 1 & 10 \\
\hline ForDeep & 280 & 0.15 & 1 & 10 \\
\hline GrassShal & 380 & 0.15 & 1 & 10 \\
\hline GrassDeep & 180 & 0.15 & 1 & 10 \\
\hline SoilShal & 380 & 0.15 & 1 & 10 \\
\hline SoilDeep & 380 & 0.15 & 1 & 10 \\
\hline Urb & 280 & 0.15 & 1 & 10 \\
\hline $\mathrm{Fp}$ & 50 & 0.15 & 1 & 10 \\
\hline Water & 50 & 0.15 & 1 & 10 \\
\hline CS & 10 & & & \\
\hline CI & 100 & & & \\
\hline $\mathrm{CB}$ & 1000 & & & \\
\hline \multicolumn{5}{|l|}{ Sub-basin 6} \\
\hline AgrShal & 300 & 0.15 & 1 & 10 \\
\hline AgrDeep & 500 & 0.15 & 1 & 10 \\
\hline ForShal & 300 & 0.15 & 1 & 10 \\
\hline ForDeep & 600 & 0.15 & 1 & 10 \\
\hline GrassShal & 800 & 0.15 & 1 & 10 \\
\hline GrassDeep & 300 & 0.15 & 1 & 10 \\
\hline SoilShal & 500 & 0.15 & 1 & 10 \\
\hline SoilDeep & 300 & 0.15 & 1 & 10 \\
\hline Urb & 500 & 0.15 & 1 & 10 \\
\hline $\mathrm{Fp}$ & 100 & 0.15 & 1 & 10 \\
\hline Water & 100 & 0.15 & 1 & 10 \\
\hline CS & 10 & & & \\
\hline
\end{tabular}


Table 3 (continued)

\begin{tabular}{|c|c|c|c|c|}
\hline \multirow[t]{2}{*}{ HRU } & \multicolumn{4}{|l|}{ Parameters } \\
\hline & $\mathrm{Wm}(\mathrm{mm})$ & $\mathrm{b}(-)$ & $\mathrm{Kbas}(\mathrm{mm} / \mathrm{d})$ & $\operatorname{Kint}(\mathrm{mm} / \mathrm{d})$ \\
\hline $\mathrm{CI}$ & 100 & & & \\
\hline CB & 1000 & & & \\
\hline \multicolumn{5}{|l|}{ Sub-basin 7} \\
\hline AgrShal & 180 & 0.15 & 1 & 10 \\
\hline AgrDeep & 280 & 0.15 & 1 & 10 \\
\hline ForShal & 180 & 0.15 & 1 & 10 \\
\hline ForDeep & 280 & 0.15 & 1 & 10 \\
\hline GrassShal & 380 & 0.15 & 1 & 10 \\
\hline GrassDeep & 180 & 0.15 & 1 & 10 \\
\hline SoilShal & 380 & 0.15 & 1 & 10 \\
\hline SoilDeep & 180 & 0.15 & 1 & 10 \\
\hline Urb & 380 & 0.15 & 1 & 10 \\
\hline $\mathrm{Fp}$ & 50 & 0.15 & 1 & 10 \\
\hline Water & 50 & 0.15 & 1 & 10 \\
\hline $\mathrm{CS}$ & 10 & & & \\
\hline CI & 100 & & & \\
\hline $\mathrm{CB}$ & 1000 & & & \\
\hline \multicolumn{5}{|l|}{ Sub-basin 8} \\
\hline AgrShal & 50 & 0.15 & 1 & 10 \\
\hline AgrDeep & 100 & 0.15 & 1 & 10 \\
\hline ForShal & 50 & 0.15 & 1 & 10 \\
\hline ForDeep & 100 & 0.15 & 1 & 10 \\
\hline GrassShal & 50 & 0.15 & 1 & 10 \\
\hline GrassDeep & 100 & 0.15 & 1 & 10 \\
\hline SoilShal & 50 & 0.15 & 1 & 10 \\
\hline SoilDeep & 100 & 0.15 & 1 & 10 \\
\hline Urb & 50 & 0.15 & 1 & 10 \\
\hline $\mathrm{Fp}$ & 50 & 0.15 & 1 & 10 \\
\hline Water & 50 & 0.15 & 1 & 10 \\
\hline CS & 10 & & & \\
\hline CI & 100 & & & \\
\hline $\mathrm{CB}$ & 1000 & & & \\
\hline
\end{tabular}

HRU's names are: agriculture with shallow soil (AgrShal), agriculture with deep soil (AgrDeep), forest with shallow soil (ForShal), forest with deep soil (ForDeep), grasslands with shallow soil (GrassShal), grasslands with deep soil (GrassDeep), shallow, bare soil (SoilShal), deep, bare soil (SoilDeep), urban areas (Urb), floodplains (Fp) and open water (Water) 


\section{References}

Alfieri L, Salamon P, Bianchi A et al (2013) Advances in pan-European flood hazard mapping. Hydrol Process. https://doi.org/10.1002/hyp.9947

Avisse N, Tilmant A, Müller MF, Zhang H (2017) Monitoring small reservoirs' storage with satellite remote sensing in inaccessible areas. Hydrol Earth Syst Sci 21:6445-6459. https://doi.org/10.5194/ hess-21-6445-2017

Ayalew TB, Krajewski WF, Mantilla R (2013) Exploring the effect of reservoir storage on peak discharge frequency. J Hydrol Eng 18:1697-1708. https://doi.org/10.1061/(ASCE)HE.1943-5584.0000721

Barraqué B (2017) The common property issue in flood control through land use in France. J Flood Risk Manag 10:182-194. https://doi.org/10.1111/jfr3.12092

Bates PD, De Roo APJ (2000) A simple raster-based model for flood inundation simulation. J Hydrol. https ://doi.org/10.1016/S0022-1694(00)00278-X

Bates PD, Horritt MS, Fewtrell TJ (2010) A simple inertial formulation of the shallow water equations for efficient two-dimensional flood inundation modelling. J Hydrol. https://doi.org/10.1016/j.jhydr ol.2010.03.027

Biancamaria S, Bates PD, Boone A, Mognard NM (2009) Large-scale coupled hydrologic and hydraulic modelling of the $\mathrm{Ob}$ river in Siberia. J Hydrol 379:136-150. https://doi.org/10.1016/j.jhydr ol.2009.09.054

Blöschl G, Gaál L, Hall J et al (2015) Increasing river floods: fiction or reality? Wiley Interdiscip Rev Water 2:329-344. https://doi.org/10.1002/wat2.1079

Bonnema M, Hossain F (2019) Assessing the potential of the surface water and ocean topography mission for reservoir monitoring in the Mekong River Basin. Water Resour Res 55:444-461. https://doi. org/10.1029/2018WR023743

Bonnema M, Sikder S, Miao Y et al (2016) Understanding satellite-based monthly-to-seasonal reservoir outflow estimation as a function of hydrologic controls. Water Resour Res 52:4095-4115. https://doi. org/10.1002/2015WR017830

Casagrande L, Tomasella J, dos Santos Alvalá RC et al (2017) Early flood warning in the Itajaí-Açu River basin using numerical weather forecasting and hydrological modeling. Nat Hazards 88:741-757. https ://doi.org/10.1007/s11069-017-2889-0

Collischonn W, Allasia D, da Silva BC, Tucci CEM (2007) The MGB-IPH model for large-scale rainfallrunoff modelling. Hydrol Sci J. https://doi.org/10.1623/hysj.52.5.878

da Paz AR, Collischonn W, Tucci CEM, Padovani CR (2011) Large-scale modelling of channel flow and floodplain inundation dynamics and its application to the Pantanal (Brazil). Hydrol Process 25:14981516. https://doi.org/10.1002/hyp.7926

Dargahi B, Setegn SG (2011) Combined 3D hydrodynamic and watershed modelling of Lake Tana, Ethiopia. J Hydrol 398:44-64. https://doi.org/10.1016/j.jhydrol.2010.12.009

Di Baldassarre G, Kooy M, Kemerink JS, Brandimarte L (2013) Towards understanding the dynamic behaviour of floodplains as human-water systems. Hydrol Earth Syst Sci 17:3235-3244. https://doi. org/10.5194/hess-17-3235-2013

Di Baldassarre G, Kreibich H, Vorogushyn S et al (2018) Hess Opinions: an interdisciplinary research agenda to explore the unintended consequences of structural flood protection. Hydrol Earth Syst Sci 22:5629-5637. https://doi.org/10.5194/hess-22-5629-2018

Döll P, Fiedler K, Zhang J (2009) Global-scale analysis of river flow alterations due to water withdrawals and reservoirs. Hydrol Earth Syst Sci. https://doi.org/10.5194/hess-13-2413-2009

Duan Z, Bastiaanssen WGM (2013) Estimating water volume variations in lakes and reservoirs from four operational satellite altimetry databases and satellite imagery data. Remote Sens Environ 134:403416. https://doi.org/10.1016/j.rse.2013.03.010

EM-DAT (2012) The OFDA/CRED International Disaster Database. http://www.emdat.be. Accessed 2 Oct 2018

Falter D, Dung NV, Vorogushyn S et al (2016) Continuous, large-scale simulation model for flood risk assessments: proof-of-concept. J Flood Risk Manag 9:3-21. https://doi.org/10.1111/jfr3.12105

Fan FM, Schwanenberg D, Alvarado R et al (2016) Performance of deterministic and probabilistic hydrological forecasts for the short-term optimization of a tropical hydropower reservoir. Water Resour Manag. https://doi.org/10.1007/s11269-016-1377-8

Felder G, Zischg A, Weingartner R (2017) The effect of coupling hydrologic and hydrodynamic models on probable maximum flood estimation. J Hydrol 550:157-165. https://doi.org/10.1016/j.jhydr ol.2017.04.052

Fleischmann A, Siqueira V, Paris A et al (2018) Modelling hydrologic and hydrodynamic processes in basins with large semi-arid wetlands. J Hydrol 561:943-959. https://doi.org/10.1016/j.jhydrol.2018.04.041 
Fleischmann A, Paiva R, Collischonn W (2019) Can regional to continental river hydrodynamic models be locally relevant? A cross-scale comparison. J Hydrol X 3:100027. https://doi.org/10.1016/j.hydro a.2019.100027

Frank B (2003) Uma história das enchentes e seus ensinamentos. In: Edifurb (ed) Enchentes na Bacia do Itajaí: 20 anos de experiências, 1st edn. Blumenau, pp 15-62

Fread D (1992) Flow routing. In: Maidment DR (ed) Handbook of hydrology

Gao H, Birkett C, Lettenmaier DP (2012) Global monitoring of large reservoir storage from satellite remote sensing. Water Resour Res 48:1-12. https://doi.org/10.1029/2012WR012063

Gao S, Liu P, Pan Z et al (2019) Incorporating reservoir impacts into flood frequency distribution functions. J Hydrol 568:234-246. https://doi.org/10.1016/j.jhydrol.2018.10.061

Getirana A, Peters-Lidard C, Rodell M, Bates PD (2017) Trade-off between cost and accuracy in large-scale surface water dynamic modeling. Water Resour Res 53:4942-4955. https://doi.org/10.1002/2017W R020519

Green CH, Parker DJ, Tunstall SM, Hazard F (2000) Assessment of flood control and management options, $165 \mathrm{p}$

Gül GO, Harmancioğlu N, Gül A (2010) A combined hydrologic and hydraulic modeling approach for testing efficiency of structural flood control measures. Nat Hazards 54:245-260. https://doi. org/10.1007/s11069-009-9464-2

Hanasaki N, Kanae S, Oki T (2006) A reservoir operation scheme for global river routing models. J Hydrol 327:22-41. https://doi.org/10.1016/j.jhydrol.2005.11.011

Hirabayashi Y, Mahendran R, Koirala S et al (2013) Global flood risk under climate change. Nat Clim Change. https://doi.org/10.1038/nclimate1911

Hoch JM, Haag AV, Van Dam A et al (2017a) Assessing the impact of hydrodynamics on large-scale flood wave propagation-a case study for the Amazon Basin. Hydrol Earth Syst Sci 21:117-132. https://doi.org/10.5194/hess-21-117-2017

Hoch JM, Neal JC, Baart F et al (2017b) GLOFRIM v1.0-A globally applicable computational framework for integrated hydrological-hydrodynamic modelling. Geosci Model Dev 10:3913-3929. https ://doi.org/10.5194/gmd-10-3913-2017

Horritt MS, Bates PD (2002) Evaluation of 1D and 2D numerical models for predicting river flood inundation. J Hydrol 268:87-99. https://doi.org/10.1016/S0022-1694(02)00121-X

Igarapé (2018) Artigo estratégico 29: Migrantes invisíveis: a crise de deslocamento forçado no Brasil. https://igarape.org.br/wp-content/uploads/2018/03/Migrantes-invisíveis.pdf

Itajaí C do (2010) Plano de Recursos Hídricos da Bacia do Itajaí (Water management plano of Itajaí River Basin)

JICA (2011) Estudo Preparatório para o Projeto de Prevenção e Mitigação de Desastres na Bacia do Rio Itajaí

Kirchner JW (2006) Getting the right answers for the right reasons: linking measurements, analyses, and models to advance the science of hydrology. Water Resour Res. https://doi.org/10.1029/2005W R004362

Latrubesse EM, Arima EY, Dunne T et al (2017) Damming the rivers of the Amazon basin. Nature 546:363-369. https://doi.org/10.1038/nature22333

Lehner B, Liermann CR, Revenga C et al (2011) High-resolution mapping of the world's reservoirs and dams for sustainable river-flow management. Front Ecol Environ 9:494-502. https://doi. org/10.1890/100125

Leopold LB, Maddock TJ (1953) The hydraulic geometry of stream channels and some physiographic implications

Li Y, Zhang Q, Yao J et al (2014) Hydrodynamic and hydrological modeling of the Poyang Lake catchment system in China. J Hydrol Eng 19:607-616. https://doi.org/10.1061/(ASCE)HE.19435584.0000835

Lopes VAR, Fan FM, Pontes PRM et al (2018) A first integrated modelling of a river-lagoon large-scale hydrological system for forecasting purposes. J Hydrol 565:177-196. https://doi.org/10.1016/j. jhydrol.2018.08.011

Mateo CM, Hanasaki N, Komori D et al (2014) Assessing the impacts of reservoir operation to floodplain inundation by combining hydrological, reservoir management, and hydrodynamic models. Water Resour Res 50:7245-7266. https://doi.org/10.1002/2013WR014845

Munar AM, Cavalcanti JR, Bravo JM et al (2018) Coupling large-scale hydrological and hydrodynamic modeling: toward a better comprehension of watershed-shallow lake processes. J Hydrol 564:424441. https://doi.org/10.1016/j.jhydrol.2018.07.045 
Neal J, Schumann G, Bates P (2012) A subgrid channel model for simulating river hydraulics and floodplain inundation over large and data sparse areas. Water Resour Res 48:1-16. https://doi. org/10.1029/2012WR012514

Nilsson C, Reidy CA, Dynesius M, Revenga C (2005) Fragmentation and flow regulation of the world's large river systems. Science (80-) 308:405-408. https://doi.org/10.1126/science.1107887

Nobre AD, Cuartas LA, Momo MR et al (2016) HAND contour: a new proxy predictor of inundation extent. Hydrol Process 30:320-333. https://doi.org/10.1002/hyp.10581

Paiva R, Buarque DC, Collischonn W et al (2013) Large-scale hydrologic and hydrodynamic modeling of the Amazon River basin. Water Resour Res 49:1226-1243. https://doi.org/10.1002/wrcr.20067

Pappenberger F, Dutra E, Wetterhall F, Cloke HL (2012) Deriving global flood hazard maps of fluvial floods through a physical model cascade. Hydrol Earth Syst Sci 16:4143-4156. https://doi. org/10.5194/hess-16-4143-2012

Paquet E, Garavaglia F, Garçon R, Gailhard J (2013) The SCHADEX method: a semi-continuous rainfall-runoff simulation for extreme flood estimation. J Hydrol 495:23-37. https://doi.org/10.1016/j. jhydrol.2013.04.045

Pinheiro A, Frank B (2003) Obras de controle de cheias. In: Edifurb (ed) Enchentes na Bacia do Itajaí. Blumenau, pp 143-172

Pokhrel Y, Shin S, Lin Z et al (2018) Potential disruption of flood dynamics in the lower Mekong River Basin due to upstream flow regulation. Sci Rep 8:17767. https://doi.org/10.1038/s41598-018-35823 $-4$

Pontes PRM, Fan FM, Fleischmann AS et al (2017) MGB-IPH model for hydrological and hydraulic simulation of large floodplain river systems coupled with open source GIS. Environ Model Softw 94:1-20. https://doi.org/10.1016/j.envsoft.2017.03.029

Rennó CD, Nobre AD, Cuartas LA et al (2008) HAND, a new terrain descriptor using SRTM-DEM: mapping terra-firme rainforest environments in Amazonia. Remote Sens Environ. https://doi.org/10.1016/j. rse.2008.03.018

Ribeiro Neto A, da Paz AR, Marengo JA, Chou SC (2016) Hydrological processes and climate change in hydrographic regions of Brazil. J Water Resour Prot 08:1103-1127. https://doi.org/10.4236/jwarp .2016.812087

Rodrigues LN, Sano EE, Steenhuis TS, Passo DP (2012) Estimation of small reservoir storage capacities with remote sensing in the Brazilian Savannah Region. Water Resour Manag 26:873-882. https://doi. org/10.1007/s11269-011-9941-8

Rudorff CM, Melack JM, Bates PD (2014) Flooding dynamics on the lower Amazon floodplain: 1. Hydraulic controls on water elevation, inundation extent, and river-floodplain discharge. Water Resour Res 50:619-634. https://doi.org/10.1002/2013WR014091

Schumann GJP, Neal JC, Voisin N et al (2013) A first large-scale flood inundation forecasting model. Water Resour Res 49:6248-6257. https://doi.org/10.1002/wrcr.20521

Seibert SP, Skublics D, Ehret U (2014) The potential of coordinated reservoir operation for flood mitigation in large basins - a case study on the Bavarian Danube using coupled hydrological-hydrodynamic models. J Hydrol 517:1128-1144. https://doi.org/10.1016/j.jhydrol.2014.06.048

Shin S, Pokhrel Y, Miguez-Macho G (2019) High-resolution modeling of reservoir release and storage dynamics at the continental scale. Water Resour Res 55:787-810. https://doi.org/10.1029/2018W R023025

Siqueira VA, Collischonn W, Fan FM, Chou SC (2016a) Ensemble flood forecasting based on operational forecasts of the regional Eta EPS in the Taquari-Antas basin. RBRH 21:587-602. https://doi. org/10.1590/2318-0331.011616004

Siqueira VA, Fleischmann A, Jardim PF et al (2016b) IPH-Hydro Tools: a GIS coupled tool for watershed topology acquisition in an open-source environment. Rev Bras Recur Hídricos 21:274-287. https://doi. org/10.21168/rbrh.v21n1.p274-287

Siqueira VA, Paiva RCD, Fleischmann AS et al (2018) Toward continental hydrologic-hydrodynamic modeling in South America. Hydrol Earth Syst Sci 22:4815-4842. https://doi.org/10.5194/ hess-22-4815-2018

Speckhann GA, Borges Chaffe PL, Fabris Goerl R et al (2018) Flood hazard mapping in Southern Brazil: a combination of flow frequency analysis and the HAND model. Hydrol Sci J 63:87-100. https://doi. org/10.1080/02626667.2017.1409896

Su C, Chen X (2019) Assessing the effects of reservoirs on extreme flows using nonstationary flood frequency models with the modified reservoir index as a covariate. Adv Water Resour 124:29-40. https:// doi.org/10.1016/j.advwatres.2018.12.004 
Tanaka T, Tachikawa Y, Iachikawa Y, Yorozu K (2017) Impact assessment of upstream flooding on extreme flood frequency analysis by incorporating a flood-inundation model for flood risk assessment. J Hydrol 554:370-382. https://doi.org/10.1016/j.jhydrol.2017.09.012

Tanaka T, Yoshioka H, Siev S et al (2018) An integrated hydrological-hydraulic model for simulating surface water flows of a shallow lake surrounded by large floodplains. Water 10:1213. https://doi. org/10.3390/w10091213

USACE USAC of E (2010) HEC-RAS River Analysis System: Hydraulic Reference Manual, Version 4.1. Davis, CA

Winsemius HC, Aerts JCJH, Van Beek LPH et al (2016) Global drivers of future river flood risk. Nat Clim Change 6:381-385. https://doi.org/10.1038/nclimate2893

Wu B, Wang G, Wang Z et al (2017) Integrated hydrologic and hydrodynamic modeling to assess water exchange in a data-scarce reservoir. J Hydrol 555:15-30. https://doi.org/10.1016/j.jhydrol.2017.09.057

Yamazaki D, Kanae S, Kim H, Oki T (2011) A physically based description of floodplain inundation dynamics in a global river routing model. Water Resour Res 47:1-21. https://doi.org/10.1029/2010W R009726

Yamazaki D, de Almeida GAM, Bates PD (2013) Improving computational efficiency in global river models by implementing the local inertial flow equation and a vector-based river network map. Water Resour Res 49:7221-7235. https://doi.org/10.1002/wrcr.20552

Yazdi J, Salehi Neyshabouri SAA (2012) Optimal design of flood-control multi-reservoir system on a watershed scale. Nat Hazards 63:629-646. https://doi.org/10.1007/s11069-012-0169-6

Yigzaw W, Li H-Y, Demissie Y et al (2018) A new global storage-area-depth dataset for modeling reservoirs in land surface and earth system models. Water Resour Res. https://doi.org/10.1029/2017WR022040

Yoon Y, Beighley E (2015) Simulating streamflow on regulated rivers using characteristic reservoir storage patterns derived from synthetic remote sensing data. Hydrol Process 29:2014-2026. https://doi. org/10.1002/hyp.10342

Yoshimoto S, Amarnath G (2018) Application of a flood inundation model to analyze the potential impacts of a flood control plan in Mundeni Aru river basin, Sri Lanka. Nat Hazards 91:491-513. https://doi. org/10.1007/s11069-017-3143-5

Zajac Z, Revilla-Romero B, Salamon P et al (2017) The impact of lake and reservoir parameterization on global streamflow simulation. J Hydrol 548:552-568. https://doi.org/10.1016/j.jhydrol.2017.03.022

Zhang S, Gao H, Naz BS (2014) Monitoring reservoir storage in South Asia from multisatellite remote sensing. Water Resour Res 50:8927-8943. https://doi.org/10.1002/2014WR015829

Zhang L, Lu J, Chen X et al (2017) Stream flow simulation and verification in ungauged zones by coupling hydrological and hydrodynamic models: a case study of the Poyang Lake ungauged zone. Hydrol Earth Syst Sci 21:5847-5861. https://doi.org/10.5194/hess-21-5847-2017

Zhou T, Nijssen B, Gao H, Lettenmaier DP (2016) The contribution of reservoirs to global land surface water storage variations. J Hydrometeorol 17:309-325. https://doi.org/10.1175/JHM-D-15-0002.1

Publisher's Note Springer Nature remains neutral with regard to jurisdictional claims in published maps and institutional affiliations. 